$6 \frac{1}{6} 193950$

事
WINCO-1093

April 1992

DELETED

VERSION

\title{
ICPP Special Fuels \\ Canning and Characterization Facility
}
D. L. Sire
C. L. Bendixsen
E. F. Armstrong
R. N. Henry
G. B. Frandsen

UNCLASSIFIED

Reviewing Official: Don R. Alexander

Date: April 27, 1992

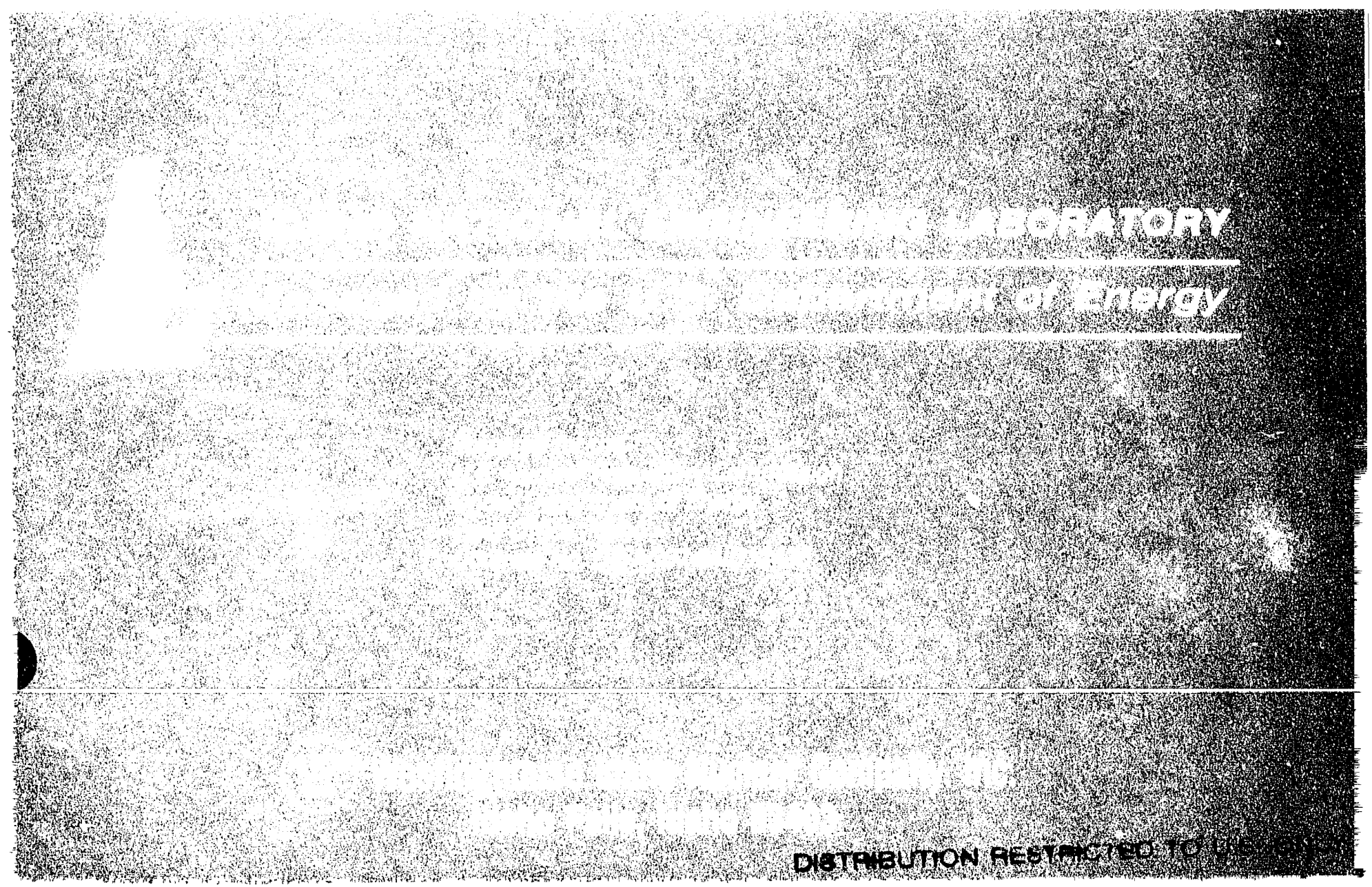




\title{
ICPP Special Fuels \\ Canning and Characterization Facility
}
D. L. Sire
C. L. Bendixsen
E. F. Armstrong
R. N. Henry
G. B. Frandsen

April 1992

UNCLASSIFIED

Reviewing Official: Don R. Alexander

Date: April 27, 1992

DEI.ETED VERSION; ORIGINAL=UCNI

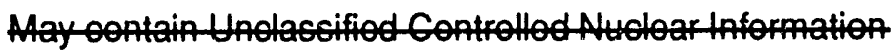

6ubjo to cotion 148 of tho Alomis Enorgy At 1064 , at a (42 US6 2168). Appovat by tho

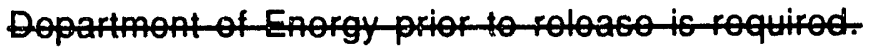

\section{DISCLAIMER}

This report was prepared as an account of work sponsored by an agency of the United States Government. Neither the United States Government nor any agency thereof, nor any of their employees, makes any warranty, express or implied, or assumes any legal liability or responsibility for the accuracy, completeness, or usefulness of any information, apparatus, product, or process disclosed, or represents that its use would not infringe privately owned rights. Reference herein to any specific commercial product, process, or service by trade name, trademark, manufacturer, or otherwise does not necessarily constitute or imply its endorsement, recommendation, or favoring by the United States Government or any agency thereof. The views and opinions of authors expressed herein do not necessarily state or reflect those of the United States Government or any agency thereof.

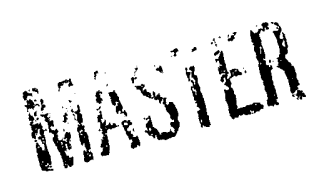


The authors would like to express our appreciation to all the people who made contributions to this document. In particular, we wish to express our thanks to N. A. Chipman, A. B. Christensen, R. D. Denney, D. W. Siddoway, A. L. Olson, W. A. Owca, J. G. Scott, E. L. Ricks, S. L. Porter, K. E. Streeper, J. H. McDaniel, C. J. Woolstenhume, D. E. Sheldon, and L. J. Toomer. 


\section{EXECUTIVE SUMMARY}

This report examines the functional mission of a Special Fuels Canning and Characterization Facility (SFCCF) for the Idaho Chemical Processing Plant (ICPP) and presents justification for its implementation as part of Westinghouse Idaho Nuclear Co., Inc. (WINCO) long-range plans. The SFCCF would be built as the first phase of an overall facility for dispositioning special fuels. Issues related to feasibility, cost, and preconceptual design criteria are also discussed in this report. A preconceptual facility layout based on existing information was developed to enhance the preconceptual design criteria and support a rough order-of-magnitude cost estimate for the construction of the SFCCF.

The U. S. Department of Energy (DOE) is the landlord of a large quantity of spent nuclear fuel and related materials. A significant quantity of this inventory, approximately $730,000 \mathrm{~kg}$ total fuel mass, is labeled as "special fuel" because no specific processing technique and/or facility to disposition this material is available in the NMP complex. The dispositioning of this fuel is especially complex because of the variety of fuel types. Of these special fuels, approximately $90 \% w t$ are stored at the INEL. Timely dispositioning of the fuels would avoid expenditures of funds for a second generation of storage facilities at the INEL and other DOE facilities and would demonstrate to the public that solutions to nuclear fuel dispositioning exist and that a plan is being executed.

The SFCCF is required to characterize, verify the storage can contents, and, if necessary, recan the special fuels to help assure safe, interim storage (i.e. fission product containment and criticality control) until the special fuels processing facility is operating. This facility would also include the capability to "condition" the special fuels in preparation for final dispositioning. The present need for a facility to characterize special fuels at the ICPP was illustrated in 1991 by the Custom Process Dissolver incident. In this incident, it is believed that a material incompatible with the dissolvent produced an explosion. If the SFCCF had been available and in service, this aberration could have been detected and the incident possibly avoided. Additional need for fuel characterization could result if (1) inspection of canned material is required to verify its content and the physical integrity of the fuel; (2) the balance of the off- 
site special fuels are shipped to the INEL for consolidated dispositioning, and verification of content is required upon receipt; (3) a decision is made to direct dispose some or all of the special fuels; or (4) some of the special fuels are classified as waste.

This report furnishes a preconceptual cost estimate for the construction of a SFCCF at the ICPP. The following related feasibility issues are also addressed; (1) impacts on the facility design related to spent fuel reprocessing or direct disposal, (2) advantages and disadvantages of constructing this facility as part of an overall special fuels dispositioning facility, and (3) processing all special fuels within the NMP complex through the SFCCF. Consolidation of all special fuel dispositioning within the NMP complex at the INEL is recommended and could provide significant cost savings.

The SFCCF would be located near the Fuel Processing Restoration (FPR) Facility and the Fluorinel Dissolution Process and Fuel Storage (FAST) facility. The construction of the SFCCF as the first stage of an overall dispositioning facility is estimated (preconceptual, rough-order-ofmagnitude) at approximately $\$ 100$ million (1991 dollars). The preconceptual facility design is sized to accommodate all special fuels within the NMP complex; however, a more in-depth conceptual design is necessary for verification.

It is estimated that up to 20 people will be needed to operate the facility (day shift only) and to provide the necessary support functions. The majority of new costs would be for facility maintenance. Annual maintenance and operating costs for the SFCCF are estimated to be approximately $\$ 6$ million/year as part of an integrated dispositioning facility.

Appendix $A$ to this report contains an updated listing of special fuels at the INEL, potential processing techniques, preliminary identification of waste forms if the special fuel is direct disposed, and a brief summary of present canning needs. The processing techniques are only potential possibilities for reprocessing some of the special fuels in existing facilities. They are provided to help scope the reprocessing capabilities and requirements. These suggestions are not actions committed to by 
WINCO or DOE since they would first have to be incorporated into the overall ICPP reprocessing, construction, and facility upgrade master schedules to determine if they were practical. To determine how and if this reprocessing could be accomplished in the manner described would require additional evaluations, flow sheet development, and pilot plant work, and is beyond the scope of this report.

It is therefore recommended that the following actions be pursued:

- Obtain funding to develop a conceptual design for a SFCCF at the ICPP. The conceptual design would verify and enhance the facility requirements, layouts, and cost estimate. This conceptual design would also investigate the cost benefits of integrating this facility with any other existing or future dispositioning facilities at the ICPP. The conceptual design would also evaluate different facility configurations to determine the optimum plant layout for interfacing with associated facilities and systems.

- Establish the equipment and process flow sheet requirements assuming all special fuels are reprocessed (one waste form).

- Development of a "Technical Bases Document" by WINCO for the canning, conditioning, obtaining of sample elements, and analysis of samples associated with the SFCCF.

- Verify the process flow sheet during laboratory experiments. These experiments should include remote support work, conditioning and sampling techniques, and inspection requirements.

- Continue to enhance all available information on all special fuels. Appendix $A$ of this report provides the current physical characteristics and chemical compositions.

- Continue to monitor the establishment of repository criteria to determine the impacts of characterization requirements on design. 


\section{CONTENTS}

EXECUTIVE SUMMARY........................

1. INTRODUCTION $\ldots \ldots \ldots \ldots \ldots \ldots \ldots \ldots \ldots \ldots \ldots \ldots \ldots \ldots$

2. FUEL CONDITIONING, CANNING, \& CHARACTERIZATION

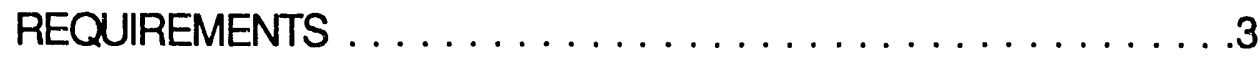

$2.1 \quad$ INTRODUCTION $\ldots \ldots \ldots \ldots \ldots \ldots \ldots \ldots \ldots \ldots$

2.2 FUEL CONDITIONING $\ldots \ldots \ldots \ldots \ldots \ldots \ldots \ldots \ldots$

2.3 FUEL CANNING $\ldots \ldots \ldots \ldots \ldots \ldots \ldots \ldots \ldots \ldots \ldots$

2.4 FUEL CHARACTERIZATION $\ldots \ldots \ldots \ldots \ldots \ldots \ldots \ldots$

2.5 FUEL CONDITIONING/CHARACTERIZATION TECHNIQUES . . .8

3. FUJEL CANNING AND CHARACTERIZATION FACILITY $\ldots \ldots \ldots \ldots 11$

3.1 FACILITY INTERFACE $\ldots \ldots \ldots \ldots \ldots \ldots \ldots \ldots \ldots \ldots \ldots$

3.2 FACILITY DESCRIPTION ..................

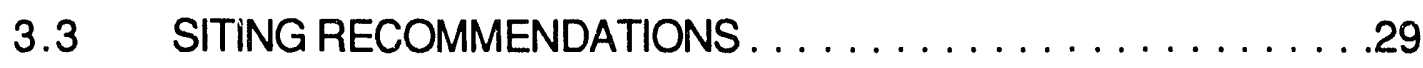

4. COST ESTIMATES AND ECONOMICS $\ldots \ldots \ldots \ldots \ldots \ldots \ldots . \ldots . \ldots$

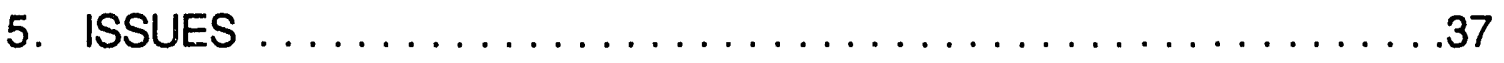

6. CONCLUSIONS AND RECOMMENDATIONS $\ldots \ldots \ldots \ldots \ldots \ldots . \ldots 39$

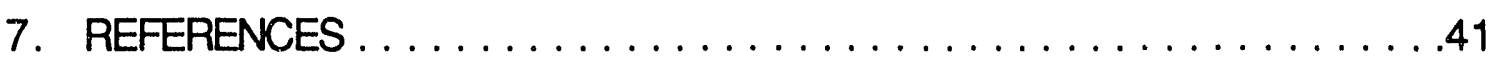




\section{APPENDIXES}
A. TABLES
B. LIST OF ACRONYMS
.55

\section{TABLES}

1. INEL Special Fuels Listing. . . . . . . . . . . . . . . . . . . . . . . . .44

2. Special Fuels at the INEL - Processing Options \& Proposals . . .46

3. Special Fuels at the INEL - Direct Disposal Forms.........48

4. INEL Special Fuels Canning/Cladding Condition $\ldots \ldots \ldots \ldots .52$

5. Summary of Costs for the SFCCF at the ICPP ...........36

\section{FIGURES}

1. Overall Special Fuels Dispositioning Facility.............12

2. SFCCF - Grade Level. . . . . . . . . . . . . . . . . . . 15

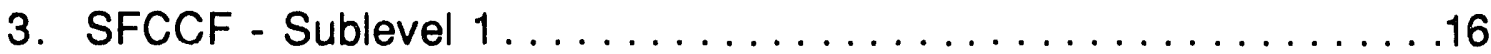

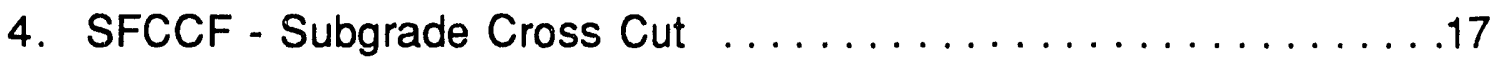

5. SFCCF - Sublevel 1 Alternate Layout $\ldots \ldots \ldots \ldots \ldots \ldots \ldots$

6. Proposed Siting for the SFCCF .................. 


\section{INTRODUCTION}

The U. S. Department of Energy (DOE) is the owner of, or has on consignment, a large quantity of nuclear fuel and targets from a variety of nuclear reactors. The majority of this inventory is associated with the Nuclear Materials Production (NMP) complex. This material must be dispositioned in a safe and controlled manner. In the late 1940s and early 1950s, specific reprocessing technologies were developed and facilities constructed to chemically disposition the majority of these NMP materials. However, approximately $730,000 \mathrm{~kg}$ total mass(1) of the remaining inventory is labeled as "special fuel" because no specific processing technique or facility to recycle this material is available in the NMP complex. The dispositioning of this fuel is especially complex because of the variety of fuel types as shown in Appendix A, Table 1(1-4). Facilities that do exist have other missions or need complete replacement to continue processing. Of the special fuels, approximately 90 percent are stored at the Idaho National Engineering Laboratory (INEL) awaiting final dispositioning(5-10).

Dispositioning these special fuels may require (1) developing new flow sheets/processing techniques, (2) constructing new chemical conditioning facilities, (3) constructing a facility to prepare the special fuel for direct disposal to a federal repository, (4) extended storage of fuels while decisions and/or dispositioning techniques are developed, or (5) some combination of the above. Regardless of which final dispositioning technique is adopted, a means to can, condition, inspect, and/or characterize this inventory of special fuels will be required.

This report addresses the requirements for a Special Fuels Canning and Characterization Facility (SFCCF) to perform the primary function of inspecting the can and its contents and reassembling or replacing the can. This facility would also permit some conditioning and inspection of these fuels. 
The report recommends that the SFCCF be built as an integral part of a future Idaho Chemical Processing Plant (ICPP) overall special fuels dispositioning facility. This design is valid whether reprocessing or direct disposal is selected as the appropriate technique for dispositioning the special fuels. This recommendation would serve to reduce the facility costs by allowing the SFCCF to share balance-of-plant features, such as heating, ventilation, and air conditioning systems, utilities, waste transfer lines, and personnel change room facilities, with the dispositioning facility.

Storage of the special fuels at the INEL is also briefly addressed in this report. Although present storage capacities are adequate, future activities could alter this condition. The discontinued use of CPP-603 for fuel storage would necessitate moving these fuels to alternate locations. Some of these fuels would require recanning in the SFCCF to allow them to be placed in dry storage. Increased receipts of Naval fuels could reduce available capacities at the ICPP. The receipt of future shipments of yet undefined special fuels, a decision to consolidate all fuel storage at one location, or a change in storage requirement criteria [i.e., fuel becomes a waste and subject to Resource Conservation and Recovery Act (RCRA)] could all result in the need for additional fuel storage capacities. In the proposed SFCCF, the special fuels would be prepared for storage; additional storage space would not be provided. This facility would be designed so that future fuel storage facilities could interface with both the SFCCF and any future special fuel dispositioning facilities.

Appendix $A$ to this report contains an updated listing of special fuels at the INEL, potential processing techniques, preliminary identification of waste forms if the special fuel is direct disposed, and a brief summary of present canning needs. The processing techniques are only potential possibilities for reprocessing some of the special fuels in existing facilities and are only provided to help scope the reprocessing capabilities and requirements. These suggestions are not actions committed to by Westinghouse Idaho Nuclear Co., Inc. (WINCO) or DOE. To determine how and if this reprocessing could be accomplished in the manner described would require additional evaluations, flow sheet development, and pilot plant work, and is beyond the scope of this report. 


\section{FUEL CHARACTERIZATION, CONDITIONING, AND CANNING REQUIREMENTS}

\subsection{Introduction}

The SFCCF would be used initially for canning fuels. Conditioning, inspection, and characterization of fuels would also be required for a variety of reasons discussed below. The following four sections address the canning, conditioning, and characterization issues. Facility description and siting recommendations are addressed in Section 3.

\subsection{Fuel Conditioning}

Special fuels within the NMP complex must be dispositioned at some time. Whether the dispositioning takes the form of reprocessing or direct disposal, some conditioning of the special fuels will be necessary. Typical conditioning examples include canning the fuel in a new can that is compatible with a specific reprocessing technique, cutting fuels into appropriate fuel handling lengths, and removing fuel meat from structural components. By equipping the facility with cells specifically designed for these types of operations and by using remote applications, this facility would condition the special fuels and would provide the first stage in an overall special fuels dispositioning process.

\subsection{Fuel Canning}

The majority of the special fuels are stored in two areas: (1) the ICPP and (2) the Test Reactor Area (TRA) and Test Area North (TAN). Although much of the special fuel at the INEL is presently contained in satisfactory canning or cladding materials, the integrity of these materials is not 
indefinite. Since a typical design life is 30 years, canning of all remaining special fuels at the INEL over the next 30 years is a distinct possibility for final dispositioning or verification of continued safe storage ir new facilities. Recanning these fuels will be necessary in the future to (1) allow some fuels presently stored in CPP-603 to be relocated in other storage areas, (2) provide facilities to can, inspect, condition, and characterize (when necessary) new receipts of off-site special fuels, (3) provide and maintain the required multiple safety barrier protection philosophy for the fuel elements, (4) contain, protect, and preserve the integrity of the fuel elements, (5) replace old cans with cans that are more robust and that have improved confinement characteristics, (6) satisfy new laws and regulations, or (7) provide material that is compatible with the reprocessing chemistry or direct disposal technique being employed to disposition the specific fuel. Tables 1-4 in Appendix A contains a summary of each special fuel stored at the INEL, proposed reprocessing options, direct disposal waste forms, and the need for canning. The direct disposal waste forms listed in Table 3 are presently being reviewed to reduce the number of waste forms. This effort is not a part of the scope of this report. This table is included to provide a perspective on the effort required to direct dispose the special fuels in a permanent repository.

\subsubsection{ICPP Stored Fuels:}

A large variety of fuels are stored at the ICPP. Many of these fuels do not require immediate canning(11). The cladding/canning material around these fuels is estimated to be suitable under current conditions for continued storage if the fuel is dispositioned in the next 10 to 15 years. However, a number of other fuels, primarily from the CPP-603 area and some fuels in dry storage, will require canning in less than 10 years. Canning existing special fuels at the ICPP may be accomplished by using one of the techniques described below. However, these methods only offer near-term canning solutions. The SFCCF would still be necessary to meet long-term canning needs.

(1) Special fuels that are presently stored underwater at the ICPP and that require canning are located in the CPP-603 facility. Present schedules show the curtailment of use of the north and middle basins of this facility by the end of the 1590s. Curtailment 
of use of the entire facility is anticipated soon thereafter. Canning on a near-term basis for many of these fuels could be done within the facility and would be performed underwater in the CPP-603 basins. Most of the fuel in CPP-603 could be canned wet using simple, relatively inexpensive equipment. Although this equipment does not currently exist, it could be designed and fabricated easily. One example of this equipment is the proposed CPP-603 Canning Station(14).

The canning of fuels underwater, however, would only provide shortterm containment for much of this fuel. Some of the fuels presently stored in CPP-603 have cladding or canning materials that have degraded to the point where the canning or cladding has been breached. Although this has allowed some fission products to be released to the basins, the water treatment system in CPP-603 has functioned effectively in removing these fission products and eliminating any health or environmental threat. Once canned in CPP603, these fuels would be transferred to the SFCCF or to other storage facilities within the ICPP. Once at the SFCCF, these fuels would be inspected and any precanning preparation performed. Then these fuels would be canned using materials and methods acceptable for long-term dry storage. The SFCCF would be especially beneficial for inspection of these fuels to determine if this condition was unusual or could be expected for the remaining inventory. The SFCCF would also provide additional features for possible conditioning of these fuels.

(2) Some fuels presently stored in CPP-749 are beginning to show deterioration of the canning materials and will require canning in the near future. The SFCCF would also provide a dedicated facility for providing appropriate inspection and canning of these fuels. In addition to those fuels stored in CPP-749, some of the special fuels presently stored in dry storage [in the CPP-603 Irradiated Fuel Storage Facility and Fuel Element Cutting Facility] require canning. Although it may be possible to can these fuels in the Graphite Storage Facility, the SFCCF would provide a facility dedicated to canning fuels in a more efficient, optimal manner. 
(3) Of the remaining fuels requiring canning, many could be canned with a proposed Fluorinel Dissolution Process (FDP) remote skid. This skid has been identified on the FY-92 General Plant Project list and can be used for preliminary, but not detailed, inspection and canning of fuels. Detailed inspection, sampling, and characterization activities would be performed in the SFCCF. Although the FDP remote skid could be used for canning fuels, its primary purpose is to uncan fuels and to consolidate cans for FDP reprocessing. Use of the FDP remote skid for canning special fuels would be inefficient, cumbersome, and would occupy the Fluorinel Dissolution Process and Fuel Storage (FAST) facility and its personnel when they may be needed to perform normal work functions (e.g., receipt of new fuels).

(4) The three non-SFCCF canning techniques described above will provide some level of canning for much of the ICPP fuel inventory. However, the three canning techniques described above will only furnish adequate near-term storage and do not provide the support functions needed to receive and inspect off-site fuel receipts or "condition" fuel for long-term storage or direct disposal. The SFCCF would also provide a facility to can fuels to allow storage in a different form (i.e., dry versus wet storage). The SFCCF would be a dedicated facility that would efficiently and safely can fuel and that would not interfere with on-going operations in other facilities. Any additional canning requirements and/or conditioning, inspection, and characterization functions would also be accomplished in the SFCCF.

\subsubsection{TRA and TAN Stored Fuels:}

Evaluation of special fuels stored at both TRA and TAN indicates that canning of these fuels is not required $(12,13)$ under current regulations because breached fuels or breached cans of fuel have been canned. Fuel cladding and/or canning materials for these special fuels are estimated to be adequate indefinitely unless subjected to corrosive conditions. Transfer of these special fuels to the ICPP for characterization, conditioning, or disposition could require that the fuel also be packaged in some acceptable type of 
containment (multiple barriers). As with the ICPP stored fuels, additional canning requirements could be mandated by those items addressed earlier in this section for continued storage or dispositioning at the INEL.

\subsection{Fuel Characterization}

The requirements that will be in effect for characterizing the special fuels at the INEL have not been determined by DOE at this time. Adequate documentation on all fuels stored at the INEL exists, but futcire requirements remain uncertain because future dispositioning processes may require new information or new safety requirements may mandate more refined input that is based on actual inspections. In recent years, the level of detail in the documentation on fuel characteristics has increased significantly. The level of detail in the documentation on fuels received 25 to 35 years ago is much less extensive. It should be noted, however, that (1) there is very little of this fuel and (2) the level of detail and degree of documentation for this fuel met the requirements in place at that time. Consequently, it is reasonable to expect additional characterization of the older special fuels could be required before they are dispositioned.

Additional justification for the need for this facility was illustrated in 1991 by the Custom Process Dissolver incident. In this incident, it is believed that a material incompatible with the dissolvent produced an explosion. If the SFCCF had been available and in service, this aberration could have been detected and the incident possibly avoided.

The SFCCF would have specifically designed features to provide efficient characterization of any or all special fuels, in addition to its canning and conditioning capabilities. This need may arise in support of developing new processing flowsheets or new rules and regulations could require examination and characterization of fuels.

Thus, potential drivers that could dictate the need for additional characterization of special fuels include the following: 
(1) Repository criteria on leach rates could also be necessary if the fuels are to be direct disposed.

(2) If the fuels will be direct disposed, verification and/or additional information on the special fuels chemistry or physical construction may be needed.

(3) Additional information could be needed for RCRA requirements if the fuel is classified as waste.

(4) If the fuels are reprocessed or chemically conditioned, additional information may be needed to establish process flow sheet chemistry.

(5) Although much of the necessary information is available, verification of fuel material details could be required to perform physical conditioning of the fuel prior to either reprocessing or direct disposal. This information includes packaging size, fuel dimensions, material strengths, size of fuel cores, and information to allow fuel meat removal from structural components.

\subsection{Fuel Conditioning/Characterization Techniques}

The conditioning and/or characterization of special fuels will necessitate a wide variety of conditioning techniques and analyses of the fuel and its components. The SFCCF would provide the facilities to perform these operations. The special fuels would be moved into a high-efficiency particulate air (HEPA) filtered cell in the SFCCF. If the fuel were contained in a cask and/or can, it would be removed from this containment. The cell would be furnished with modular support equipment and remote manipulators to perform these operations. At the completion of the conditioning or characterization process, the fuel would then be replaced in its can or placed in a new can for storage to await dispositioning.

The wide variety and types of fuel compositions, sizes, claddings, and fuel meat configurations will require modular equipment to accommodate these diverse fuels. The SFCCF would be designed with additional areas 
designated for modular assembly and hot module storage/refurbishment. The number and types of modular equipment packages would be dictated by the degree, frequency, or extent of conditioning/characterization required.

Additional studies are required to determine the optimum resolution for operations performed in the SFCCF. These studies include compiling and consolidating all available information on all special fuels. This information should specifically include physical characteristics as well as chemical compositions. Any additional studies should also include detailed evaluation of building the SFCCF as part of an overall special fuels dispositioning facility or building the SFCCF and the dispositioning facility as separate, stand-alone facilities. This topic is briefly addressed in Section 3.1, Facility Interface, and in Section 5, Issues. 


\section{FUEL CANNING AND CHARACTERIZATION FACILITY}

\subsection{Facility Interface}

The SFCCF would can and condition fuel elements for dispositioning and would allow for characterization of the special fuels, if required. Once the function was complete, the fuel would be transferred to one of the following phases of dispositioning:

(1) Continued near-term interim storage.

(2) Preparation of the fuel for dispositioning by reprocessing.

(3) Preparation of the fuel for dispositioning by direct disposal.

In order to create an efficient facility, this report recommends that the SFCCF be built as an integral part of an overall special fuels conditioning, canning, and dispositioning facility. This could be accomplished by either building the individual facilities in close proximity to each other, or more ideally, by building all of these facilities as a phased approach to a single facility.

The concept of building these functional groups as a single facility provides some definite advantages (see Figure 1). Fuel would move from the SFCCF into the dispositioning portion of the overall facility. This would reduce the distance for fuel transfers and would simplify the packaging requirements. Fuel proceeding directly to the dispositioning portion of the facility through the remote transfer channels would also eliminate the need for loading fuel into shipping casks.

If wet storage capacity were required to satisfy fuel availability for charging to a new dispositioning facility, a surge storage area could also be constructed as a portion of the integrated facility. Special fuels could be transferred from the SFCCF directly to an underwater storage transfer channel and into an underwater storage basin in the dispositioning 


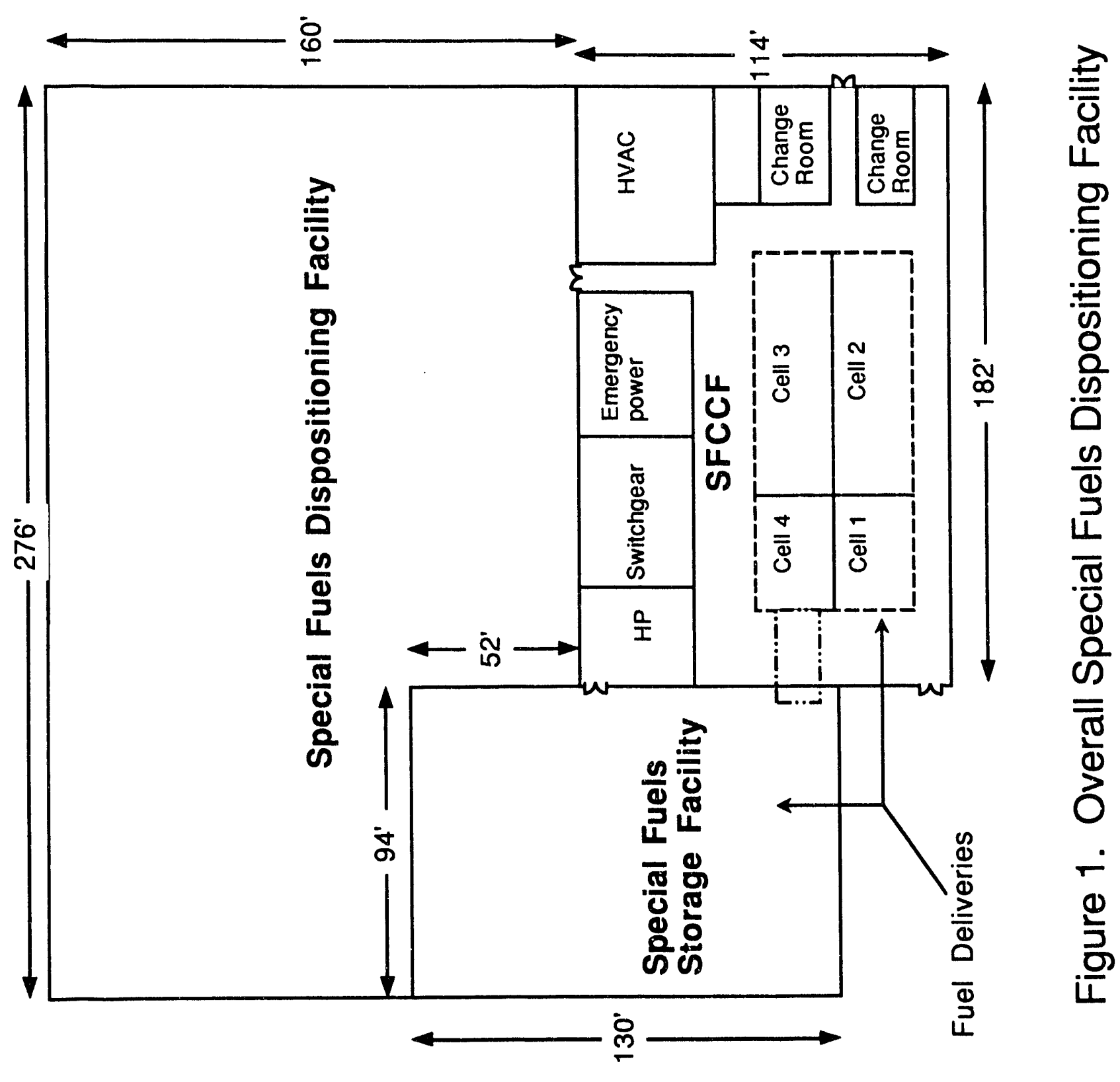


facility. If additional dry storage were needed for special fuels, the fuel could be transferred through a dry storage transfer channel to a new dry storage facility. This new dry storage could also be built in close proximity or as a part of the final dispositioning facility. The benefits from implementation of either storage option include reduced fuel handling, reduced cask loading, and reduced decontamination efforts. Also, by transferring the fuels remotely, the risk of contamination spread and radiation exposure would be reduced.

Constructing an overall special fuels dispositioning facility would also result in cost minimization. Constructing the faciity in a phased manner to produce one overall facility would allow sharing of balance-of-plant features. These include process chemical make-up areas, operator change rooms, Health Physics facilities, storage areas, loading and unloading areas, operator access corridors, heating, ventilating, and air conditioning (HVAC), utility supplies, mechanical and electrical rooms, offices, equipment, and personnel support. Other areas that could share common uses include control rooms, maintenance areas for remote manipulators and overhead cranes, areas for storage of contaminated equipment, and an emergency generator room. Other items that would reduce overall costs include elimination of some building components by the sharing of common walls, and size efficiency in building and maintaining the facility.

Combining the SFCCF with the overall special fuel dispositioning facility would reduce not only construction costs, but operational and maintenance costs over the life of the facility. It would also provide a potentially more streamlined, efficient, and safe overall dispositioning process.

\subsection{Facility Description}

The controlling factor for cell sizing in the SFCCF is dictated by the physical size required to handle the individual fuel elements and their packaging. Throughput rates for conditioning, inspecting, and/or characterizing special fuels must be accomplished in the 30- to 40-year life expectancy of the facility. The size established by physical fuel sizes is anticipated to be adequate to accommodate this throughput rate. The proposed facility size is estimated to be adequate to allow operation of 
the facility 5 days per week, day shift only. If the degree of conditioning or characterization were to increase, operation of the facility 7 days per week, 3 shifts per day would increase the facility on-line capacity by about 400 percent. This flexibility is believed to encompass the range of need for the SFCCF. Another issue affecting the sizing of the SFCCF involves the decision on whether or not to build the facility as a standalone facility or as a part of an overall conditioning, canning, characterization, and dispositioning facility. Figures 2 through 4 show a preconceptual facility layout for the SFCCF based on its construction as a part of the overall special fuels dispositioning facility. This layout is provided to help identify functional interfaces and approximate facility cell sizes. Figure 5 displays an alternate facility cell layout. This layout is not as space-efficient, but allows better interface with the remote maintenance cell. This alternate layout would have to be propagated throughout the balance of the facility. Optimized layout would require significant Architectural-Engineering (A-E) design. Figure 5 also presents a plan view of the space below the general area of the instrument transmitter room. This area would be used for module assembly and module storage and refurbishment.

An additional cell would be provided for storage of fuel elements while conditioning of other fuel is performed, and inspection or analytical results are obtained. This would enhance throughput capacity. Additional storage could be required if the conditioning/characterization operations were too time-consuming. Design of the SFCCF would be in accordance with the "Nonreactor Nuclear Facilities: Standards and Criteria Guide."

\subsubsection{Functional/Operational Requirements:}

The SFCCF would provide at least the following basic functional requirements:

(1) Loading, unloading, decontamination, and temporary storage of a variety of different-sized shipping casks, canning containers, and fuel elements.

(2) Control of alpha contamination. 


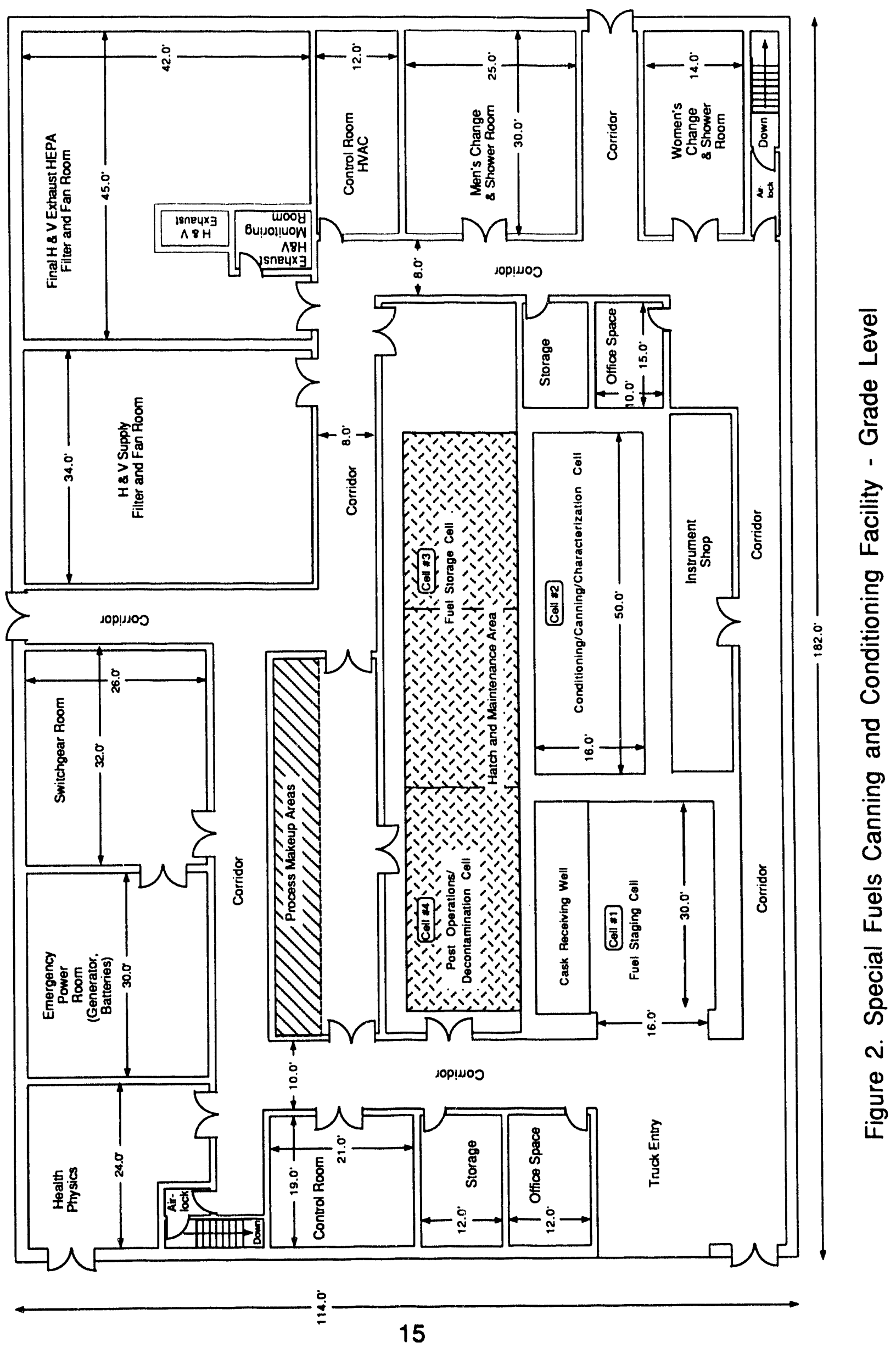




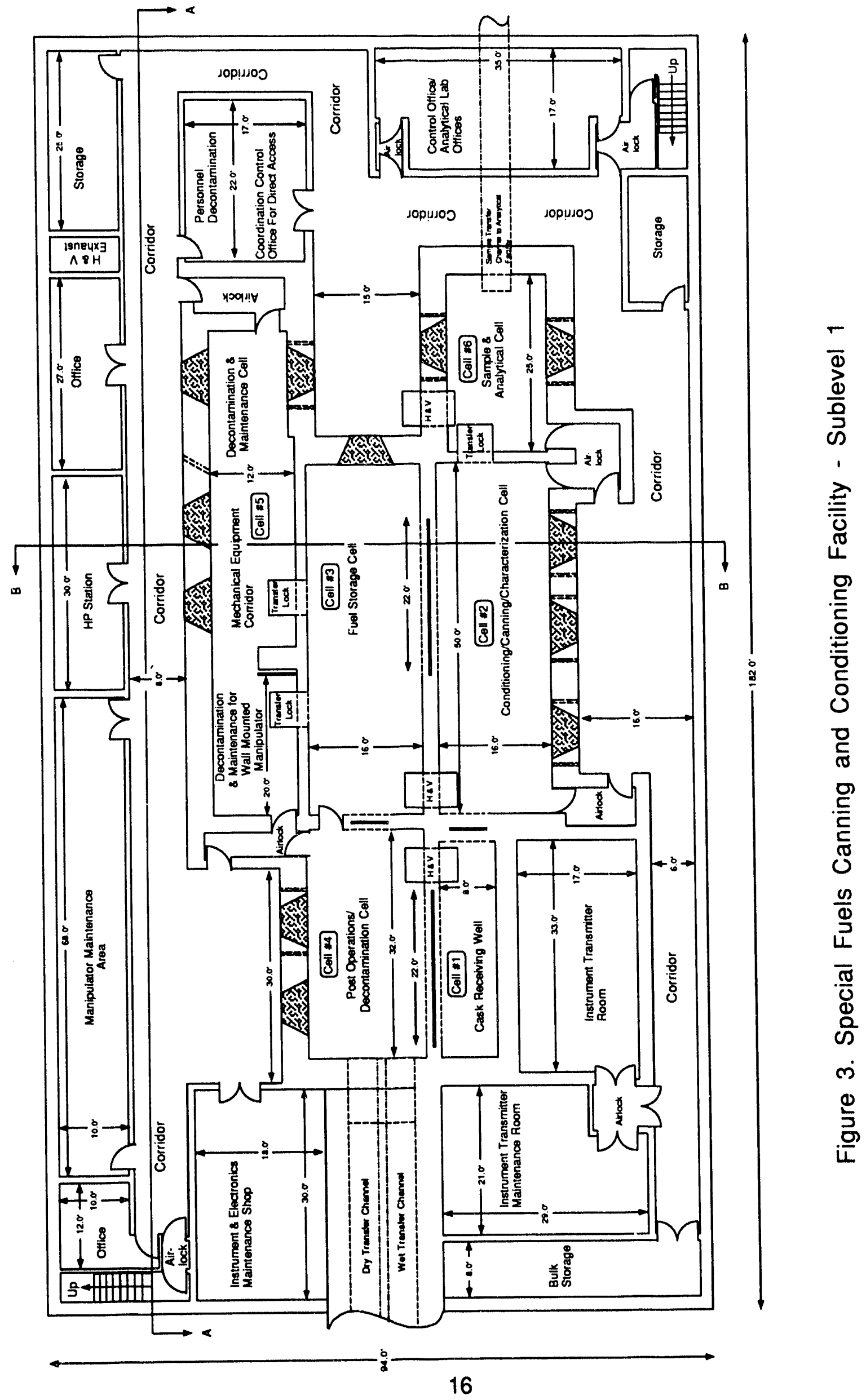



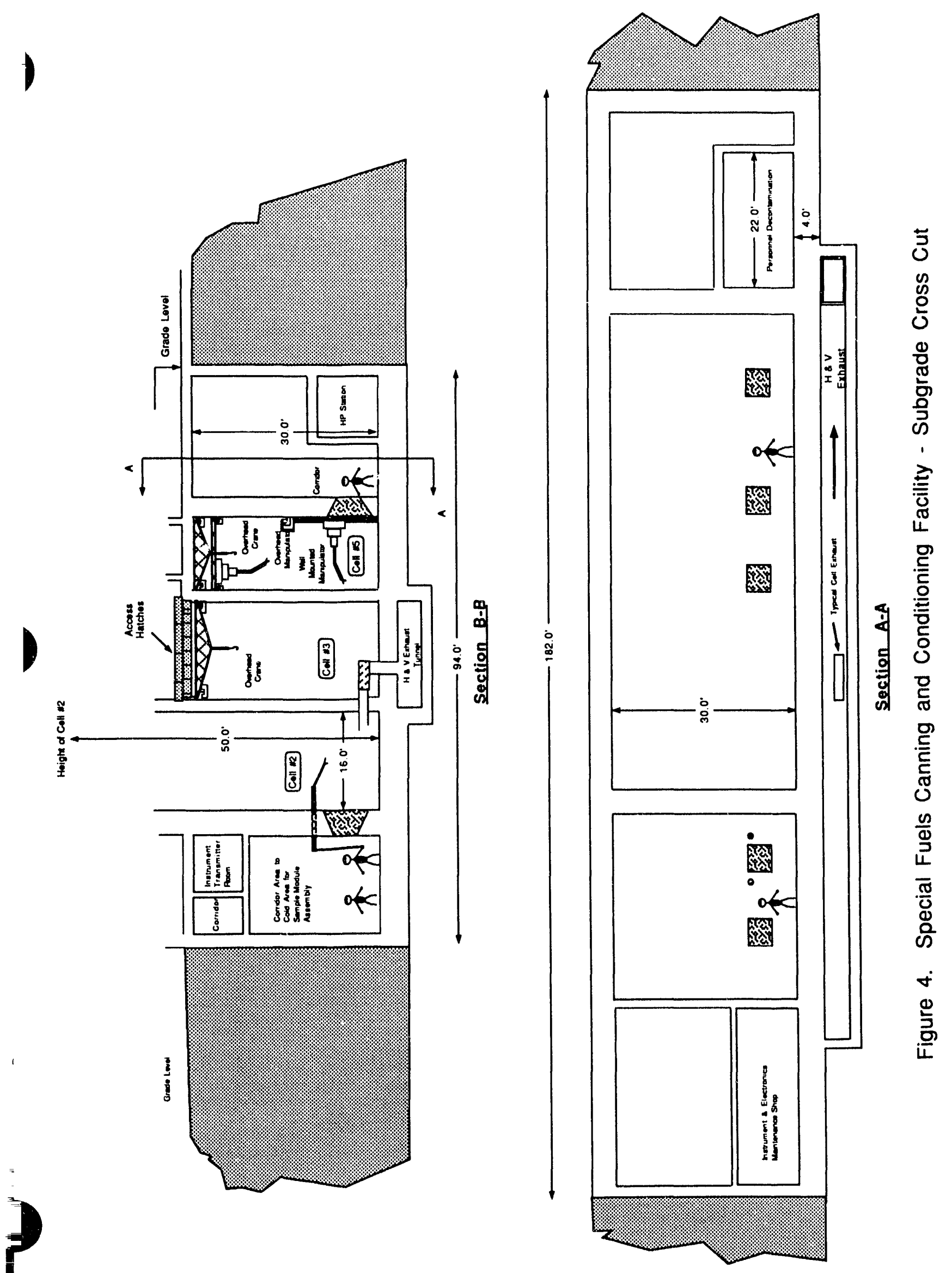


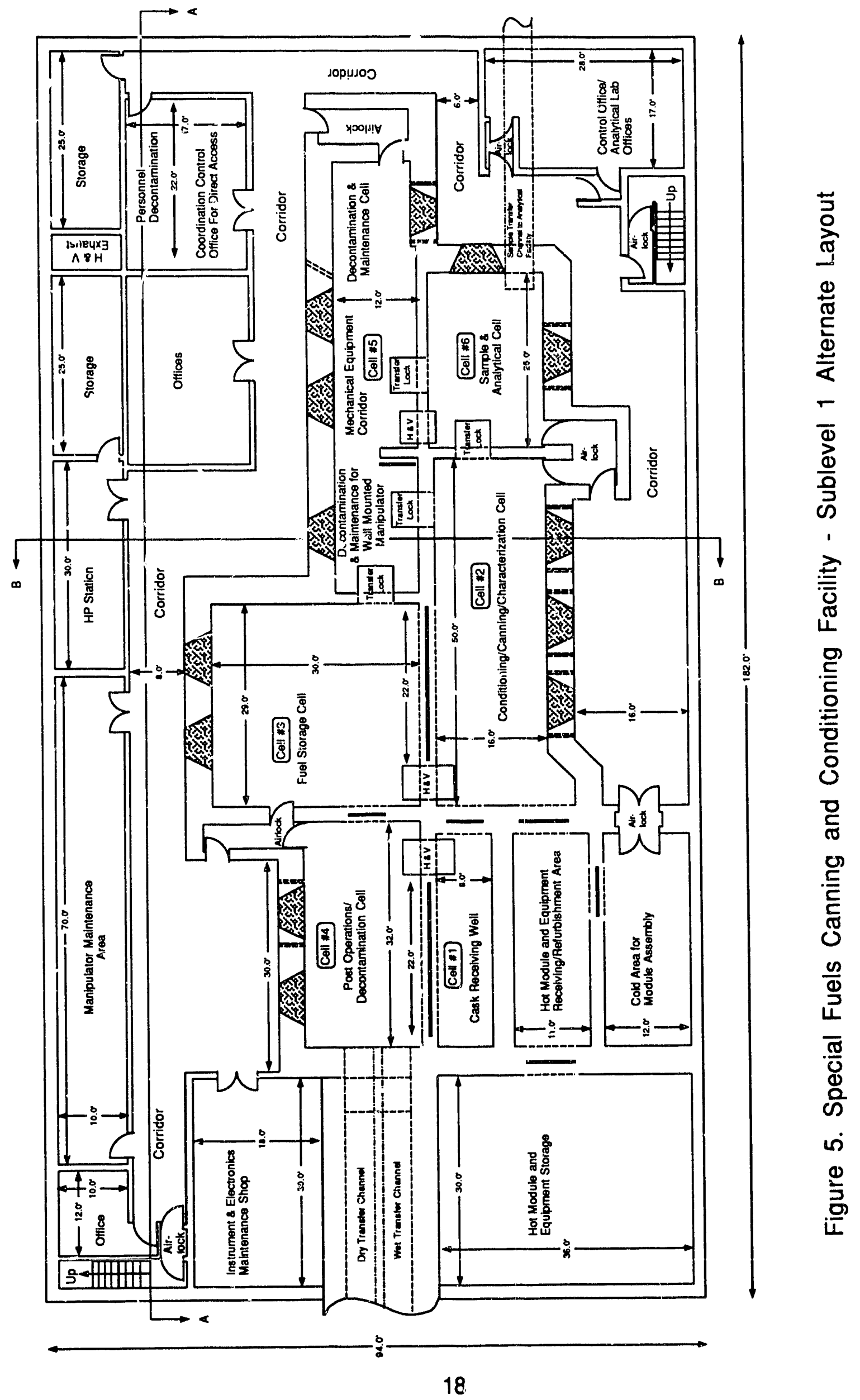


(3) Control/shielding if beta-gamma radiation sources to as-low-asreasonably-achievable (ALARA) limits.

(4) Nuclear safeguards and security.

(5) Criticality safety features and functions and radiation monitoring.

(6) Improved decontamination features for timely cell turnarounds.

(7) Remote handling capabilities (e.g., equipment, cell lighting, angles) that will adequately support all ongoing canning and characterization activities and maintenance activities.

(8) Receipt, storage, and preparation of process and decontamination chemicals.

(9) Personnel and equipment access.

(10) Functional tie-ins with required utility supplies (air, water, sewer, electricity, steam, instrument air, service waste, Process Evaporator Waste system, etc.).

(11) Remote replacement of cell support equipment.

(12) Remote capabilities for handling and moving fuel elements, cans, and/or casks.

(13) Remote sampling of fuels and transfer of these samples to an analytical laboratory.

(14) Heating, cooling, and ventilation flow based on practical energy conservation measures and on containment of contamination.

(15) HEPA filtration of all air streams that could potentially contain airborne contamination.

(16) Monitoring of facility effluents. Decontamination activities could potentially generate both airborne and liquid radioactive streams. 
Mechanical methods of obtaining fuel and cladding samples would also generate radioactive effluents.

(17) Storage of contaminated items that would be used within the cells on an intermittent basis and would not require complete decontamination until they failed.

(18) Operational features and functions that comply with industrial safety requirements.

(19) Remote packaging and removal of decontaminated process and test equipment that will permit shipping to the New Waste Calcining Facility (NWCF) Decontamination Facility or temporary storage in a shielded area.

(20) Cold mockup areas to test sampling equipment before it is placed in the hot cell to do work. This would also include storage areas for sampling modules for reuse in future fuel characterizations.

\subsubsection{System Configuration and Essential Features:}

The basic components of the new SFCCF would consist of six individual hot cells (see Figures 2 through 5 ). The hot cell areas would be supported by adjoining cold mockup areas, cask and equipment charging systems, an operating area, a process control/data readout center, a chemical makeup and storage area, a multipoint sampling station and sample transfer system, a shielded storage area for contaminated equipment, and a decontamination and packaging system. The remaining portions of the facility would include the typical balance-of-plant-type components: HVAC, electrical systems, change room, office area, etc.

\subsubsection{Facility Throughput:}

The most severe throughput condition anticipated for the SFCCF would be based on the assumption that all special fuvis would require some form of characterization. If basing the proposed facility size on physical fuel dimensions provides adequate size and throughput capacity for this assumption, the facility would be adequately sized for any facility operating basis. 
Quantities of special fuels at the INEL are typically identified as cans, elements, or rods of fuel. To determine the number of representative samples that would be performed in the SFCCF, the following criteria were employed. All fuels would require at least one sample. If the quantity of fuel were listed as cans, one sample per can would be obtained unless it were listed as scrap. Then, four samples per can would be taken. For quantities of fuel listed as elements or rods and where compositions are expected to be uniform 10 percent of the fuel would be sampled.

Using this sampling criteria, for example, the 24 cans of PULSTAR Buffalo would equire 24 separate samples. For the 50 cans of <deleted>, 200 samples would be needed. With TRIGA aluminum, the 554 elements would result in 56 samples. At the other extreme, the 2 elements of PBF $\mathrm{UO}_{2}$ $\mathrm{ZrO}_{2}-\mathrm{CaO}$ would still require one sample analysis. This would require some 4000 samples for those special fuels presently stored at the INEL. It is also assumed that each sample would require one full shift to deliver, unload, uncan, obtain a sample, recan, hold in the Fuel Storage Cell, decontaminate, and transfer back to the storage area or headend facility. Based on 250 operating days per year, all special fuels would be processed through the SFCCF in approximately 16 years. Since approximately 90 percent of all special fuels are located at the INEL, this figure would be expected to rise to about 18 years to characterize all special fuels in the NMP complex (with the exceprion of $N$ Reactor fuel). Allowing additional time to can fuel elements not being sampled, an effective operating life of about 25 years would be necessary for the SFCCF. It is estimated that the balance of special fuels in the NMP complex could be processed through the SFCCF in an additional 5 years.

In the event that fuel sampling was needed at a more aggressive rate to support dispositioning schedules, or in the event that each fuel element were to require sampling, a full-time, three-shift-per-day operation would increase on-line capacity by about 400 percent. This, coupled with a 30- to 40-year life expectancy is anticipated to be adequate to process all the special fuels through the SFCCF. A three-shift-per-day operating schedule would also provide flexibility if a great variety of conditioning/characterization were required.

The facility preconceptual layout encompasses a grade level footprint that 
is 182 feet long and 114 feet wide. Sublevel 1 is 182 feet long and 94 feet wide. Cell height on sublevel 1 is 30 feet. Grade-level operating height is 20 feet. Cell 1 is only at grade level with the exception of the cask-receiving well which continues down to the bottom of sujlevel 1 . Cells $3,4,5$, and 6 are located entirely on sublevel 1 . Cell 2 extend through both levels with a total height of 50 feet.

\subsubsection{Cell Sizing and Functions:}

The facility would consist of six shielded cells that would serve the following functions:

- In Cell 1, off-loading and on-loading of shipping packages or casks would be performed.

- In Cell 2, conditioning, canning, and/or characterization functions would be performed.

- Cell 3 would provide storage space for fuel elements/canisters while operational results were obtained, or for other delays in the next stage of the fuels processing.

- In Cell 4, post-operation activities would be performed.

- Cell 5 would provide an area for remote maintenance of hot equipment.

- Cell 6 would be used to perform remote analytical work.

The Fuel Staging Cell (Cell 1) and the Post Operations/Decontamination Cell (Cell 4) need only be sized for a fuel assembly size of 20 feet. These cells would be approximately 30 feet long to allow for the 20-foot long assembly, plus remote equipment manipulation of the assemblies, and any additional operations required, such as decontamination of the can's exterior prior to transferring it from the facility cells.

Cell 2 would be used for conditioning, canning, and characterization of the special fuels, and must be sized large enough to handle the largest sized fuel cans/elements presently stored (or that could potentially bo stored) 
at the INEL. The longest assemblies are expected to be approximately 16 to 20 feet long (commercial fuels). Cell 2 would, therefore, need to be at least 50 feet long. This would allow 20 feet for the assembly, 20 feet for the can it may be packaged in, and 10 feet of additional space for equipment, freeboard, operating room, and space to manipulate the entire special fuel assembly. The cell would also be 50 feet tall. This would allow fuel elements to be upended for unloading and recanning. This feature could allow the cell length to be reduced from 50 feet. However, for sizing purposes on a preconceptual basis, the cell sizing would be based on the need for a 50-foot-long cell.

The Fuel Storage Cell (Cell 3) would be needed for storage of fuel elements/canisters. This cell would allow fuel operations to continue in Cell 2 without interruption and would be relatively large compared to the Post Operations/Decontamination Cell and Fuel Staging Cell and would be about equal in size to the Conditioning/Operation Cell.

All other cell areas (e.g., decontamination and maintenance area for remote equipment, and access and utility corridors) would be sized accordingly to accommodate and support the four main operating cells. Noncell rooms on sublevel 1 would typically be 10 to 15 feet in height. Ceilings for these rooms would be reinforced to allow for expansion into the additional space above these rooms for future support functions.

Additional space on sublevel 1 would be reserved for such functions as cold mockup areas for testing remote equipment modules, maintenance areas for remote equipment, and hot storage for equipment modules. This space is depicted in Figure 5.

In the Fuel Staging Cell, shipping packages or casks would be off-loaded from transport equipment at ground level and set into a cask receiving well. The base of the cask receiving well would be at sublevel 1 . The fuel would then be transferred horizontally through an airlock into Cell 2 . In the Post Operations/Decontamination Cell, decontamination and any additional post-operation activities would be performed. At the completion of these activities, the fuel assembly could be transferred in one of two ways. It could be transferred back into the cask receiving well in Cell 1 for loading on transport equipment, or if the SFCCF is built as 
part of an overall integrated dispositioning facility, the fuel could be transferred from Cell 4 through a dry or wet transfer channel to either the fuel storage area or directly to the dispositioning headend.

\subsubsection{Personnel Safety, Safeguards, and Security:}

The major safety concern for future operations centers on adequate contamination and criticality control. Achieving adequate contamination control requires facility design features (including ventilation system features, airlocks, filtration, and flows directed into zones of higher contamination) that simplify the "hot" cell operations (remote equipment setups, cell decontamination, maintenance, sampling, fuel charging, etc.). The design goal for radiation exposure would be ALARA.

Enhanced safeguards and security controls would be required at locations within the facility where significant quantities of fissile materials could be accessible. Security features such as monitored access, alarm systems, closed-circui: televisions, surveillance, metal detectors, theft and diversion detection devices, and communications equipment would be required. Specific requirements would vary with the fuel characteristics. Generally, low- or zero-burn-up fuels would require more safeguards than high-burn-up fuel. Since this facility would handle fuels with varying degrees of uranium and plutonium concentrations and burn-ups, the facility would have to meet the limiting conditions established for lowor zero-burn-up highly enriched uranium (HEU) fuel and its associated plutonium content.

Nuclear material accountability requirements include material measurement, control, traceability, inventory, records, and data collection capabilities. Accountability would be required for both the fuel elements/pieces and for samples or segments removed from the fuel. Specific safeguards and security requirements for any given area vary according to the type of operation. Generally, access to the facility must be controlled to comply with radiological safety, security, nuclear materials control, and accountability requirements. Security requirements can generally be satisfied by including access controls, an alarm system, a surveillance system, nuclear material detector systems, diversion monitoring systems, guards, etc. The safeguards and security 
systems must be compatible with the ICPP system and must meet minimum DOE guidelines.

Interfaces with the existing ICPP systems would also be required to manage waste generated from decontamination and cleanup activities. Disposal of any hazardous wastes generated from these activities or in the analysis of samples or in the samples themselves would meet those requirements in force at that time. Facilities and procedures are presently in existence for the control and disposal of these wastes.

\subsubsection{Maintenance:}

The basic maintenance philosophy for this facility would be to achieve ALARA radiation exposures for plant personnel while maintaining timely maintenance support and a cost-effective design. Features would be provided for remote replacement of failed equipment in contaminated areas according to the radiation risk; i.e., the higher the risk, the greater the need for remote operation. Preventive maintenance and annual scheduled downtime for repair would help maintain a high reliability. Remote maintenance operations in the contaminated hot cells is a key element in attaining high use. Inadequate remote capabilities results in the need for extensive cell decontamination to allow personnel entry. Decontamination requires more downtime, generates additional waste, and increases personnel radiation exposures.

Failed components would be decontaminated as required to allow packaging and shipment to the Radioactive Waste Management Complex or the NWCF Decontamination Facility. Provisions for introducing replacement components into hot cells shall include contamination control and radiation shielding features. Maintenance stations would be provided at cell entries for cases when remote capabilities were not adequate and direct maintenance and/or decontamination by support personnel was required.

All cold areas would be supported by direct maintenance techniques and would include standard industrial safety features. 


\subsubsection{Process, Waste, and Utility Interfaces:}

Utility interfaces would include air (high-pressure, low-pressure, and breathing air), steam (high and low pressure), water (treated, potable, demineralized, and fire), and electrical (normal, standby, and/or emergency). Required utility connections would be made via extensions of the existing utility distribution system. Waste streams would include sewage, service waste, process equipment wastes, decontamination solutions, low-level wastes, high-level wastes, and off-gas cleanup systems. Operation of this facility is not expected to significantly impact the demand of any of the utility support systems except for emergency power. An emergency generator would be supplied as part of this facility and/or an overall dispositioning and fuel conditioning, canning, and characterization facility. Sevvage would be transferred to the existing sewage treatment plant. High-level waste generated would be transferred to the tank farm by tieing into existing high-level waste lines. Low-level waste would be sent to the Process Evaporator Waste system or the Fuel Processing Restoration (FPR) Facility for recycle or treatment. Service waste streams would be cleaned and recycled. For the purpose of this report, it is assumed that the overall dispositioning facility would supply its own service waste cleaning and recycling equipment; however, it may be possible to transfer these streams to the FPR Facility for treatment and recycle. Cell and vessel off-gas streams would be sent to a facility stack equipped with HEPA filters. Contaminated HEPA filters would be remotely handled in accordance with ICPP practices, and the generation rate from the SFCCF would not overload any future disposal system.

\subsubsection{Radiological Safety:}

Radiological safety would be provided in accordance with DOE orders. Remote area monitors and constant air monitors would be provided as required, as well as a health physics (HP) office for HP support activities. Local station alarms would be connected to a control alarm panel in the HP office and to the Radiation Safety computer system. Radiation shielding for continuous-occupancy areas would meet existing DOE and ICPP requirements. 
Confinement of radioactive materials would be provided by the use of multiple zones and pressure differentials. Each zone would consist of physical barriers such as pipe and vessel walls, cell walls, etc., and pressure differentials would be maintained to ensure airflows from zones of low contamination potential toward zones of higher contamination potential. The process piping, vessels, and off-gas systems would constitute the primary boundary, and the process cell with its directed and filtered ventilaticn system would constitute the first back-up barrier. Additional back-up would be provided by the facility structures and the associated HVAC system that surround and enclose the hot cells.

The multibarrier contamination control philosophy generally produces the following three control areas: (1) clean areas that are uncontaminated and have a very low probability of ever becoming contaminated, (2) restricted areas--clean areas that have a higher potential for becoming contaminated, and (3) controlled areas--areas that have a high contamination potential.

Special features to ensure $\alpha$-control (airlock entries, $\alpha$-monitoring, HEPA filtration, etc.) would be provided. Contamination would be controlled as close as practicable to the point of release. Pneumatic instrumentation and samplers would be isolated in cubicles, and the cubicles would be designed to contain any contamination that may escape the samplers or instrument transmitters. The cubicle would also be designed to enhance and simplify decontamination.

\subsubsection{Natura! Phenomena:}

Structures, equipment, systems, etc., would be classified in accordance with the applicable architectural and engineering standards to determine which components must meet the design basis natural phenomena (design basis earthquake, design basis flood, design basis tornado, etc.) and which must be designed in accordance with the Uniform Building Code's Seismic Zone 3 criteria as detailed in the "Nonreactor Nuclear Facilities: Standards and Criteria Guide."

\subsubsection{Fire Safety:}

Fire protection would be provided within the facility in accordance with DOE orders, National Fire Protection Association codes, and site and plant 
chemical standards. An alarm system would be provided for the facility exhaust filtration system.

\subsubsection{Industrial Safety:}

In general, the facility would be designed in accordance with the industrial safety requirements of the Occupational Safety and Health Administration and applicable DOE orders.

Systems would be placed in effect to ensure appropriate controls were in place for the process reagents and decontamination solutions, such as acids and caustics, metal salt solutions, oxidizing solutions, and others that could be prepared and used in the facility.

Alarm systems would be provided for local area evacuation and would be incorporated into the existing overall ICPP evacuation system.

\subsubsection{Environmental:}

Effluent streams from this facility would be processed through the Process Evaporator Waste system, the Liquid Effluent Treatment \& Disposal facility, or other appropriate ICPP facilities, and would be cleaned to remove contaminants to levels that permit safe release to the environment and that meet applicable DOE Orders, Environmental Protection Agency requirements, and State of Idaho regulations.

\subsubsection{Quality Assurance:}

Quality Assurance requirements would be developed for nuclear/nonnuclear and environmental considerations in accordance with applicable DOE orders. Quality Assurance criteria would include items such as inservice inspections and remote monitoring/inspections. 


\subsection{Siting Recommendations}

\subsubsection{Siting Criteria:}

The SFCCF would be located at the ICPP. Some of the basic selection criteria for siting this facility are as follows:

(1) Provide for future facility expansion and interface with future facilities.

(2) Provide a location that optimizes interface functions with the other interacting ICPP facilities and utilities.

(3) Minimize interference with existing and proposed structures.

(4) Consider subsurface conditions relative to their impact on natural phenomena design requirements.

(5) Provide access for receiving custom fuel shipping containers, chemicals, test equipment, etc.

(6) Provide good vehicular and pedestrian flow patterns.

(7) Site the facility to minimize impacts of design basis accidents at the ICPP.

(8) Minimize construction and security interface problems.

\subsubsection{Recommended Siting Location:}

The ICPP presents several locations for the SFCCF that would satisfy the above criteria. Final siting of the SFCCF would depend on how, and if, it was combined with other existing or proposed facilities at the ICPP. Following are the recommended sitings based on these considerations.

\section{Proposed Location:}

The siting location recommended by this report is in the general area between FAST and FPR Facility. Figure 6 is an excerpt from an updated version of the ICPP Area Map 2010(15) showing this proposed location. This area map also demonstrates the optimal location 
wherein the proposed special fuel dispositioning facility would be constructed as an integral facility with the SFCCF. This could reduce facility and operational costs while providing maximum operational and functional efficiency of the combined facilities. Transferring fuel directly to the dispositioning portion of the facility would also eliminate the need for loading the fuel into shipping casks. Additional study and A-E work is required to evaluate this option.

\section{Alternate Location \#1:}

If the proposed location is not acceptable, the next preferred location is adjacent to the proposed FDP Upgrade to the FAST facility. This location has many of the same benefits of combining the SFCCF with the special fuels dispositioning facility. Sharing of balance-of-plant features, HVAC systems, HP personnel, and other facility features would contribute to lowering both construction and operating costs. Additionally, the Multiple Electrolytic Headend facility is proposed for this area. Since some of the special fuels could be processed in FAST, the proximity to the SFCCF would be beneficial. The major drawbacks to this location would be in congestion, the intricacies of interfacing the common systems and features of up to four different facilities (FAST, FDP Upgrade, Multiple Electrolytic Headend, and the SFCCF), and the separation and distancing of the SFCCF from the special fuels dissolution facility.

\section{Alternate Location \#2:}

The third proposed location for the SFCCF would still be in the area between FAST and FPR Facility, but the facility would be constructed as a stand-alone facility. This proposal is the least attractive alternative of the three proposed sitings since it would most probably require total higher construction and operational costs for the SFCCF and an associated dispositioning facility as compared to either above alternative. In addition, the physical separation of the SFCCF from other facilities that it would interface with would increase the complexity of operations, increase the risks of unusual occurrences related to fuel and sample transfers, and under-utilize ICPP resources. 


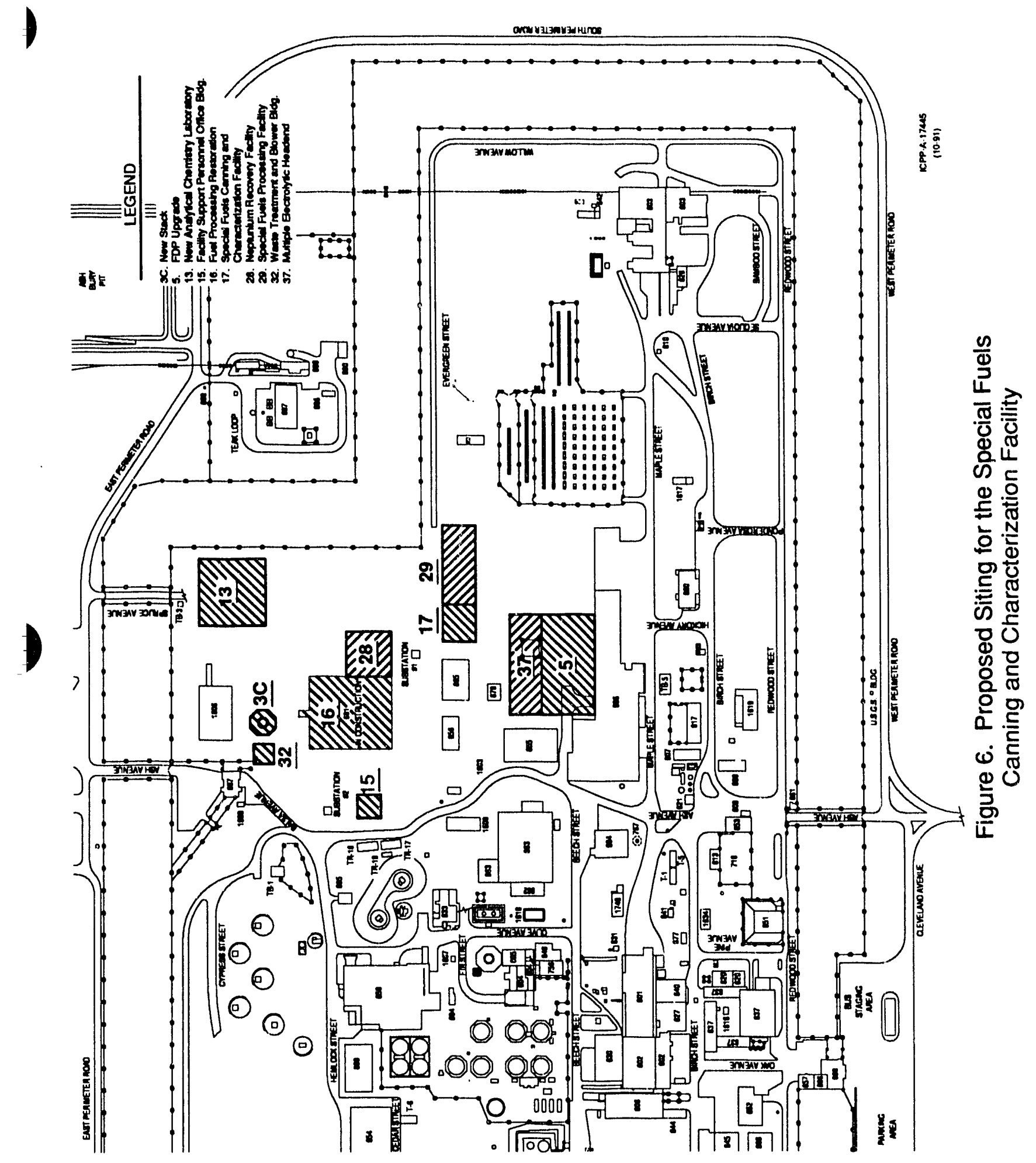




\section{COST ESTIMATES AND ECONOMICS}

The proposed SFCCF layout incorporates a remote maintenance philosophy that is ccnsistent with the NWCF, FDP, and FPR Facility designs. Based on these actual designs and costs, it is estimated that the total capital cosi for the proposed SFCCF would be approximately $\$ 100$ million in 1991 dollars (derived from FPR Facility on a cost-per-square-foot basis). This estimate assumes that the SFCCF would be built as part of an overall special fuels dispositioning facility as described in Section 3.3.2, Proposed Location. In this option, additional cost is included for sharing common costs with the othe integrated facilities. If the SFCCF were to be built as a stand-alone facility, the construction estimate would be closer to $\$ 90$ million. However, combined total construction costs for the SFCCF and for a dispositioning facility built as stand-alone facilities would be expected to be higher than it would be for one integrated facility.

One point of emphasis must be addressed in building the SFCCF as part of an overall special fuels dispositioning facility. The estimated cost of the SFCCF is approximately $\$ 100$ million in 1991 dollars based on an assumption that the SFCCF would be built as the first stage in an overall special fuels dispositioning facility. The increase in cost over that of a stand-alone facility represents the additional expense in building common features sized to accommodate all of the integrated facilities (e.g., HVAC, offices, change rooms, and waste lines). This initial increased cost would subsequently reduce the cost for building the balance of the dispositioning facility since it would not have to provide these features. The combined costs for both of these integrated facilities should therefore be minimized. Savings realized in construction costs would be supplemented by additional future savings in operating and maintenance costs for the combined facilities.

These estimates are rough order-of-magnitude (ROM), preconceptual estimates based only on facility size. More accurate estimates would require detailed information available from conceptual design. The conceptual design would clarify the facility requirements and layouts, and 
would evaluate sharing the balance-of-plant features and other common cost features with a new special fuels dispositioning facility. A conceptual design would also further refine and improve operating and maintenance cost estimates associated with this new facility. Table 5 summarizes the estimated costs for the construction and operation of the SFCCF, built as the first stage of an integrated special fuels dispositioning facility.

A conceptual design is needed to ascertain whether or not it is economically feasible and preferable to physically integrate these facilities. If an analysis determines that it is not beneficial, it would be highly advantageous to build these facilities in close proximity to one another to facilitate functional integration.

To insure facility and process integrity, more in-depth readiness reviews are now being performed on new projects as part of the required start-up and testing procedures. Based on projected costs for the FPR Facility (and other future process related facility projects at the ICPP), testing, training, procedure writing, and other associated start-up activities for the SFCCF are estimated at approximately $\$ 10$ million to $\$ 15$ million (in 1991 operating dollars).

Annual maintenance costs for the SFCCF are estimated at approximately $\$ 3$ million to $\$ 4$ million per year. Typical commercial industrial averages are in the 4- to 5- percent range based on capital costs for the respective facility. The historical average for many of the major facilities in the NMP complex has been lower than this (approximately 1 percent of capital costs). However, this has resulted in deterioration of facilities, which ultimately requires extensive and expensive capital upgrades to these facilities. The use of a 3- to 4- percent annual maintenance cost, assuming 12-months-per-year operation, would be considered appropriate for the SFCCF based on these criteria. This annual maintenance cost estimate is based on a construction cost of approximately $\$ 100$ million.

Annual operating costs would stem primarily from the addition of about 15 personnel. These 15 personnel (12 direct and three indirect) would cost approximately $\$ 1.5$ million per year. These manpower numbers are based on manning the SFCCF as part of the overall special fuels 
dispositioning facility. The total manpower number for a stand-alone facility is estimated at approximately 20 personnel. The increased manpower results from the inability to fully use and share common personnel (e.g., mechanics, HPs, and supervisors).

Other minimal operating costs would cover chemicals, other utilities, processing supplies, etc. The utility cost for operating the HVAC is estimated at approximately $\$ 50,000$ per year. The need for canning materials would be minimal because the majority of fuels received would already be canned or would not require canning, and existing canning could be reused in many cases. Total estimated nonlabor costs would be approximately $\$ 200,000$ per year to cover the miscellaneous canning materials, chemicals, other utilities, processing supplies, etc.

Total maintenance and operating costs would approximate \$6 million per year for the SFCCF portion of a fully integrated dispositioning facility and $\$ 7$ million per year for the stand-alone facility. These annual operating costs are based on day-shift-only operation of the facility. About 30 additional personnel would be required to operate the facility on a fulltime, around-the-clock basis. 


\section{TABLE 5.}

\section{Summary of Costs for the SFCCF at the ICPP}

(in millions of dollars-1991)*

Cap:tal Costs

Start-up and Testing (Initial)

Annual Maintenance Costs

Annual Operating Costs
$\$$

$\$$

$\$$

$\$$

2

" built \& operated as part of an integrated special fuels dispositiong facility 


\section{ISSUES}

The major issues affecting the proposed construction and operation of the SFCCF are (1) identification of criteria for the canning, conditioning, inspection, and characterization of special fuels, (2) determination of whether special fuels would be reprocessed or direct disposed, (3) impacts of the NMP complex reconfiguration study, and (4) whether the SFCCF should be built as a starid-alone facility or as an integrated facility with the special fuels dissolution facility. These issues are discussed in detail below.

- The first issue concerns the identification of criteria that would be used in determining which special fuels would require conditioning, canning, and/or characterization. The degree to which these operations are applied to the special fuels at the INEL could be extremely varied. In addition, new rules and regulations could require additional conditioning, examination, and characterization of fuels beyond what is presently performed and/or expected.

Compilation and consolidation of all available information on all special fuels is integral to resolving this issue and should be one of the first tasks pursued subsequent to this report. This information should specifically include physical characteristics as well as chemical compositions.

- The second issue concerns determining whether the special fuels would all be reprocessed, all will be direct disposed, or if some combination of these two options will be employed. This decision may not necessarily affect the size or other requirements for the SFCCF; however, the direct disposal option and associated characterization and packaging criteria could necessitate more extensive characterization requirements. The decision could impact sizing of common features and systems for an overall, integrated special fuels dispositioning facility. This would be important if the SFCCF were to be built first and the dispositioning facility appended at a later time. 
- The third issue concerns the present DOE NMP complex reconfiguration study. The impetus of this study is to determine the feasibility and economic benefits of combining all reprocessing capabilities at one location. Under this philosophy, the SFCCF could be used to characterize and can not only all special fuels at the INEL, but also those special fuels at other locations within the NMP complex. This could also include $N$ Reactor fuel, but only if a sampling program was implemented that consisted of a representative sampling technique that did not involve sampling of every fuel piece. In addition, any future special fuels could also be processed through the SFCCF.

- The fourth issue concerns the possibility of building the SFCCF as part of an integrated dispositioning facility. This option presents a potential savings in both construction and operating costs. The decision on whether or not to build the SFCCF as a stand-alone facility or as part of an overall dispositioning facility takes into account several factors. These factors include the type of dispositioning facility to be built (dissolution or direct disposal), funding limitations, timing schedules for the construction of the different facilities, and the interrelation of these facilities as affected by future criteria and policy decisions.

The first three issues, in some cases, involve more of a policy decision rather than a technical decision. Regardless of the technical basis for a decision on the first two issues, a policy decision will be required as a basis for each.

The fourth issue could result in a decision that is both technically and policy based. The resolution of the first two issues may affect both the decision to build the SFCCF as part of an overall, integrated special fuels dispositioning facility, and also how these facilities would be interrelated. WINCO should perform additional studies to evaluate the construction and operation of this integrated facility. If the additional study determines that this is an optimal solution, WINCO should take the lead in promoting it to DOE. However, this decision will still be a policy decision. 


\section{CONCLUSIONS AND RECOMMENDATIONS}

The construction of the SFCCF at the ICPP would provide the INEL and the NMP complex with the capability to can, condition, and characterize special fuels that are stored at the INEL or brought to the INEL from elsewhere within the NMP complex. The special fuels stored at the INEL account for about 90 percent of the approximately $730,000 \mathrm{~kg}$ total within the entire NMP complex. Regardless of any decisions on how these special fuels would be dispositioned, either by direct disposal or by reprocessing, the SFCCF would be a necessary part of the dispositioning activity. Reprocessing techniques would determine the extent of conditioning necessary, and regulations would determine the degree of canning and characterization required for these special fuels prior to their dispositioning. WINCO may require additional information to make appropriate and relevant decisions for the actual dispositioning processes.

The estimated construction cost for a new SFCCF is approximately $\$ 100$ million (1991 dollars). This estimate is based on constructing the SFCCF as part of an overall total special fuels dispositioning facility at the ICPP. Building the SFCCF as a stand-alone facility could lower this cost to the $\$ 90$ million range. However, building the facility as part of a total dispositioning facility could reduce the total capital costs compared to what would be needed to build all these facilities as stand-alone structures. Even if the facilities were to be built as stand-alone facilities, it is recommended that they be built in close proximity to each other to permit them to functionally interface. The annual operating and maintenance costs for the SFCCF are estimated to be approximately $\$ 6$ million per year for an integrated dispositioning facility. This cost could rise to approximately $\$ 7$ million per year for a stand-alone facility. This new, modern facility would provide an effective means for the safe and efficient dispositioning of special fuels stored at the INEL.

Successful construction and operation of the SFCCF at the ICPP could be strengthened by the following actions. It is therefore recommended that these actions be pursued. 
- Obtain funding to perform a conceptual design for building a SFCCF at the ICPP. The conceptual design would verify and enhance the facility requirements, layouts, and cost estimate. This effort would include an evaluation on sharing the balance-of-plant features, systems, and personnel with an integrated dispositioning facility. The conceptual design would further refine and verify operating and maintenance costs associated with this new facility. This conceptual design would also investigate the possibility and cost benefits of integrating this facility into any other existing or future headend facilities at the ICPP. The study would also evaluate and appraise different facility configurations to determine an optimum plant layout for interfacing with associated facilities and systems.

- Establish additional equipment and process flow sheet requirements.

- Development of a "Technical Bases Document" by WINCO for the canning, conditioning, obtaining of sample elements, and analysis of samples associated with the SFCCF. The document would provide an augmented technological foundation for conceptual design.

- Verify the process flow sheet during laboratory experiments. A specific item that may need to be addressed could be answered by pilot plant testing of mechanical means of obtaining samples. These experiments should also include remote support work, other sampling techniques, and inspection requirements.

- Compile and consolidate all additional available information on all special fuels. This information should specifically include physical characteristics as well as chemical compositions.

- Continue to monitor the establishment of repository criteria to determine the impacts of characterization capabilities on design. 


\section{REFERENCES}

1. J. Bruno, D. E. Luke, A. L. Olson, W. A. Owca, Special Fuels: Processing Versus Direct Disposal, WIN-297, February 1990

2. Wir-30-90, B. R. Wheeler letter to W. C. Moffitt, "Update of Letter EWP-251-86 for Disposition of Fuels," April 18, 1990

3. Sidd-54-89, D. W. Siddoway letter to Dr. C. R. Nichols, "Draft Report on RCRA Status of INEL Stored Fuels," August 4, 1989

4. JGS-9-86, J. G. Scott letter to B. R. Wheeler, "Processing Recommendation and Disposition of Fuel," May 28, 1986

5. L. F. Ermold, LFE-150-91 to M. J. Bonkoski, "Quarterly Irradiated Fuel Receipt Forecast," dated April 10, 1991

6. D. A. Knecht, DAK-25-91 to M. J. Bonkoski, "CY-90 Integrated Data Base Information," dated April 11, 1991

7. J. W. Jones, JWJ-219-90 to Distribution, "Annual Inventory Assessment (FY-91)," dated November 5, 1990

8. Report - H00047, MBA 126, "JSG Inventory," dated Feb. 7, 1991

9. Report - H00047, MBA 117, "JSG Inventory," dated Dec. 10, 1990

10. Report - H00047, MBA 107, "JSG Inventory," dated March 4, 1991

11. Personal conversations with E. F. Armstrong (ICPP) in February and March 1991

12. Personal conversations with S.L. Porter and K. E. Streeper (TAN) on March 121991 
13. Personal conversations with J. H. McDaniel, L. J. Toomer, E. L. Ricks, C. J. Woolstenhume, and D. E. Sheldon (TRA) on March 5 \& 12, 1991

14. B. E. Griebenow (EG\&G), D. W. Ketchen (General Atomics), Feasibility Study: CPP-603 Canning Station, April 1989

15. GGS-16-90, G. G. Simpson letter to W. C. Moffitt, et al, "ICPP 2010 Proposed New Facilities," May 31, 1990

16. D. L. Sire, et al, ICPP Special Fuels Canning and Characterization Eacility, WIN-320, February 1992

Added to Deleted Version 
1

\section{APPENDIX A}

TABLES

) 


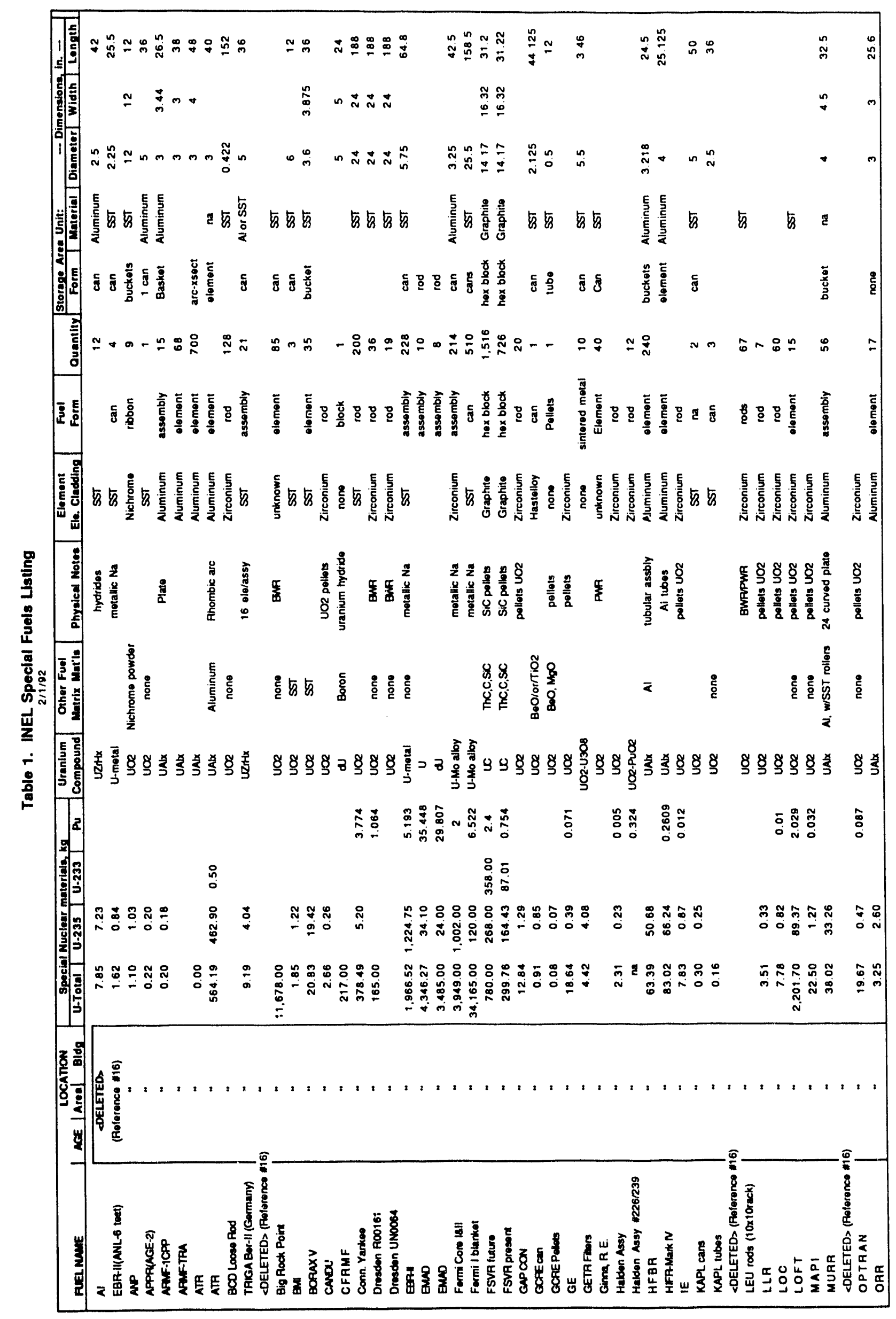




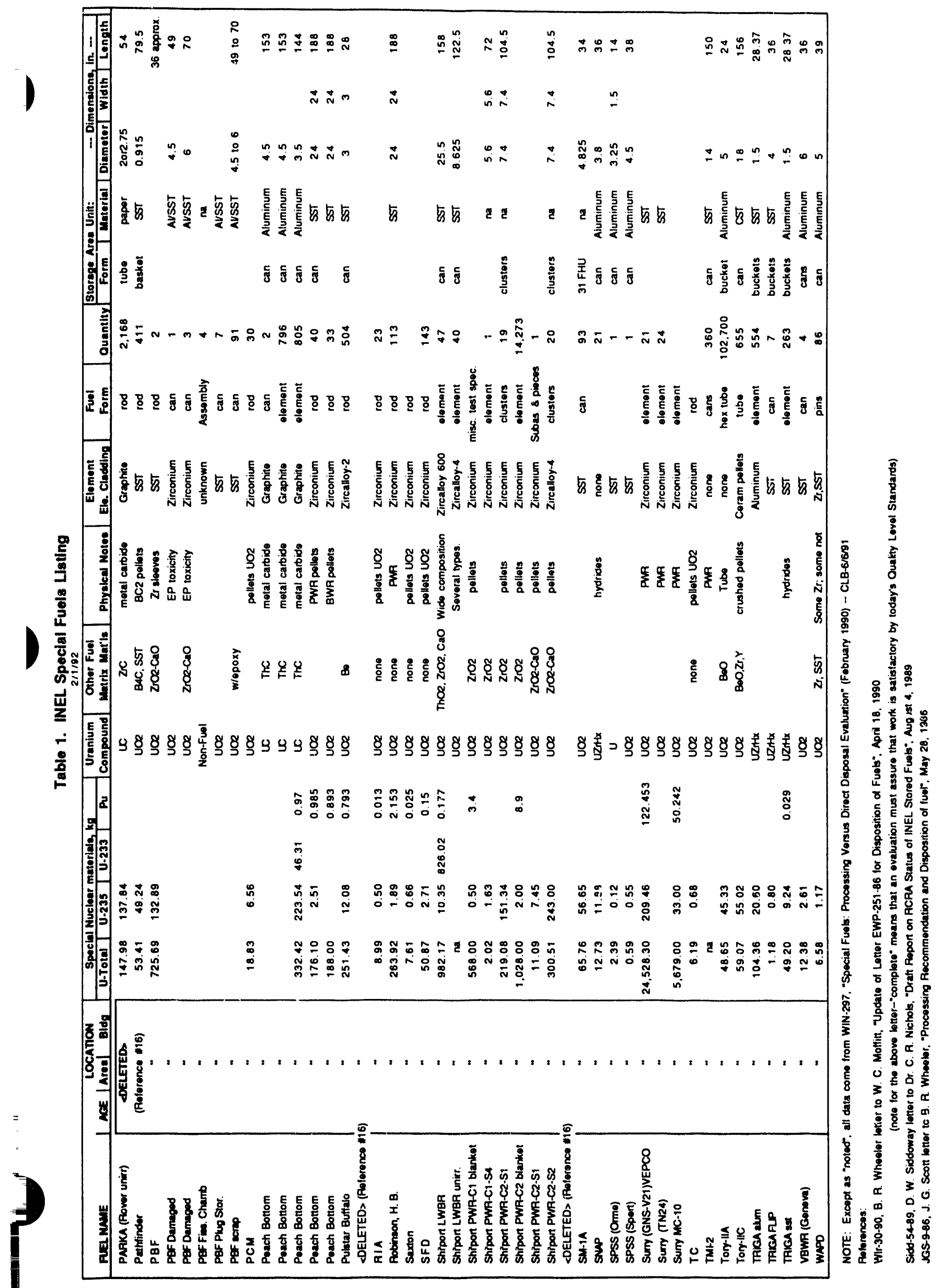




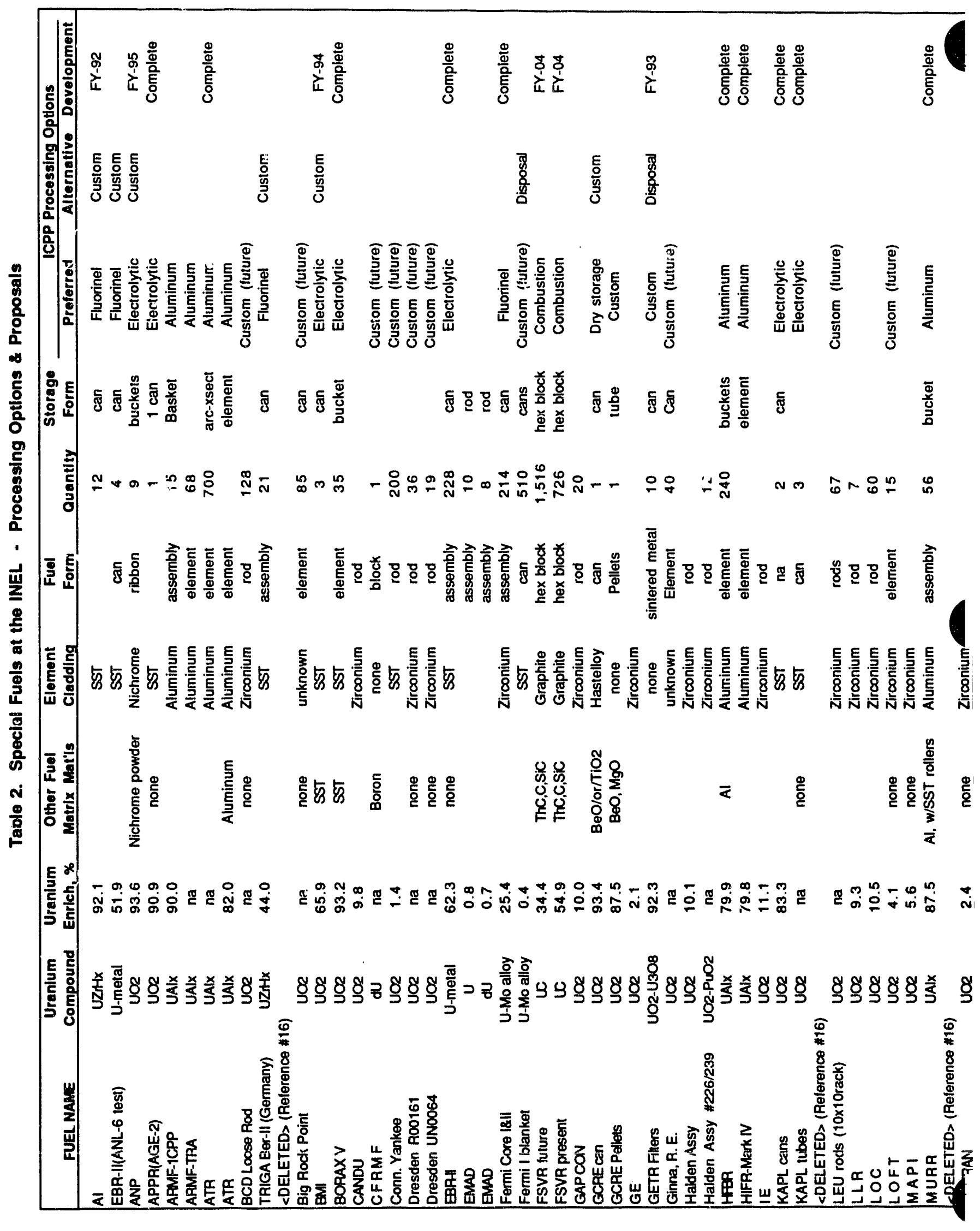




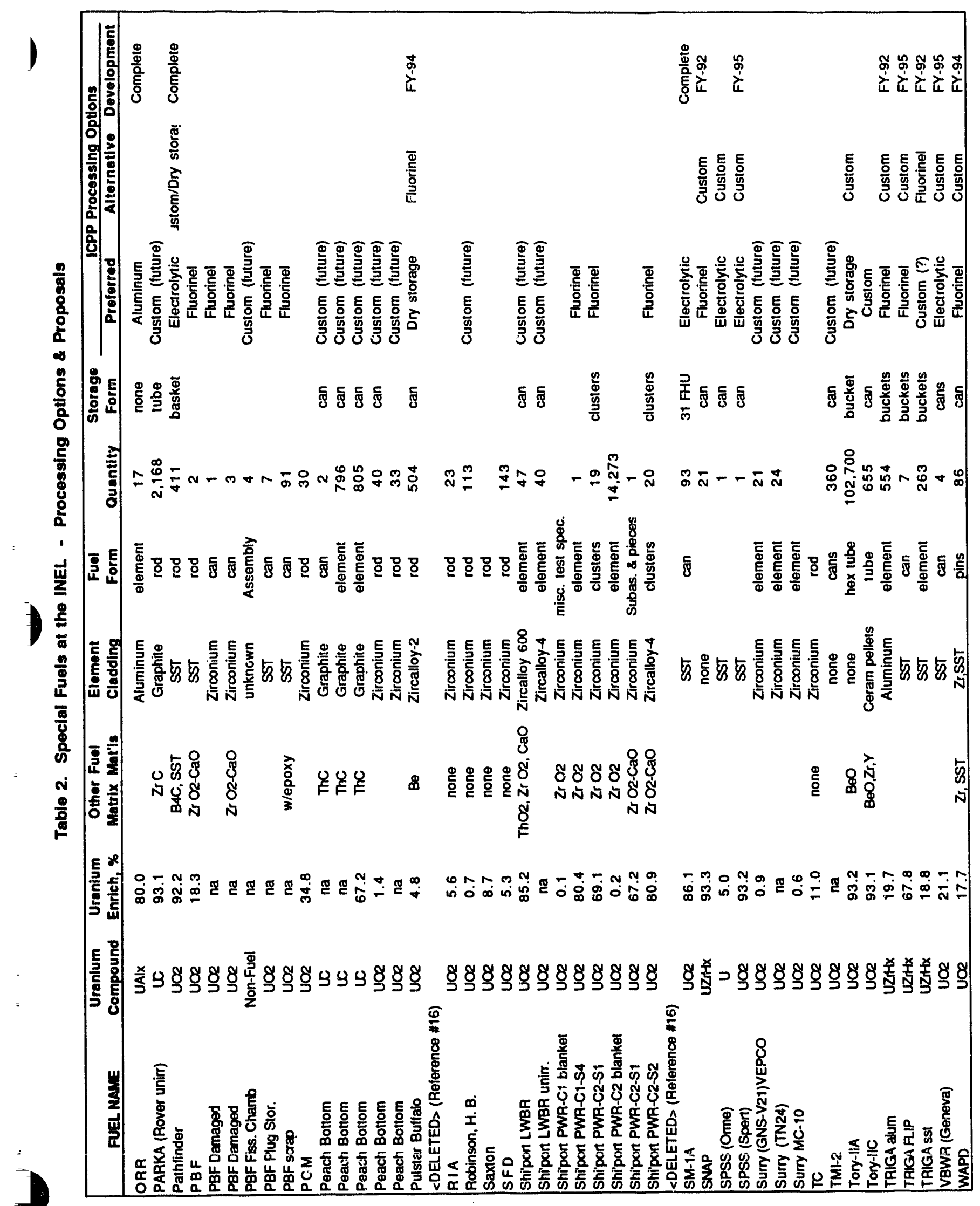




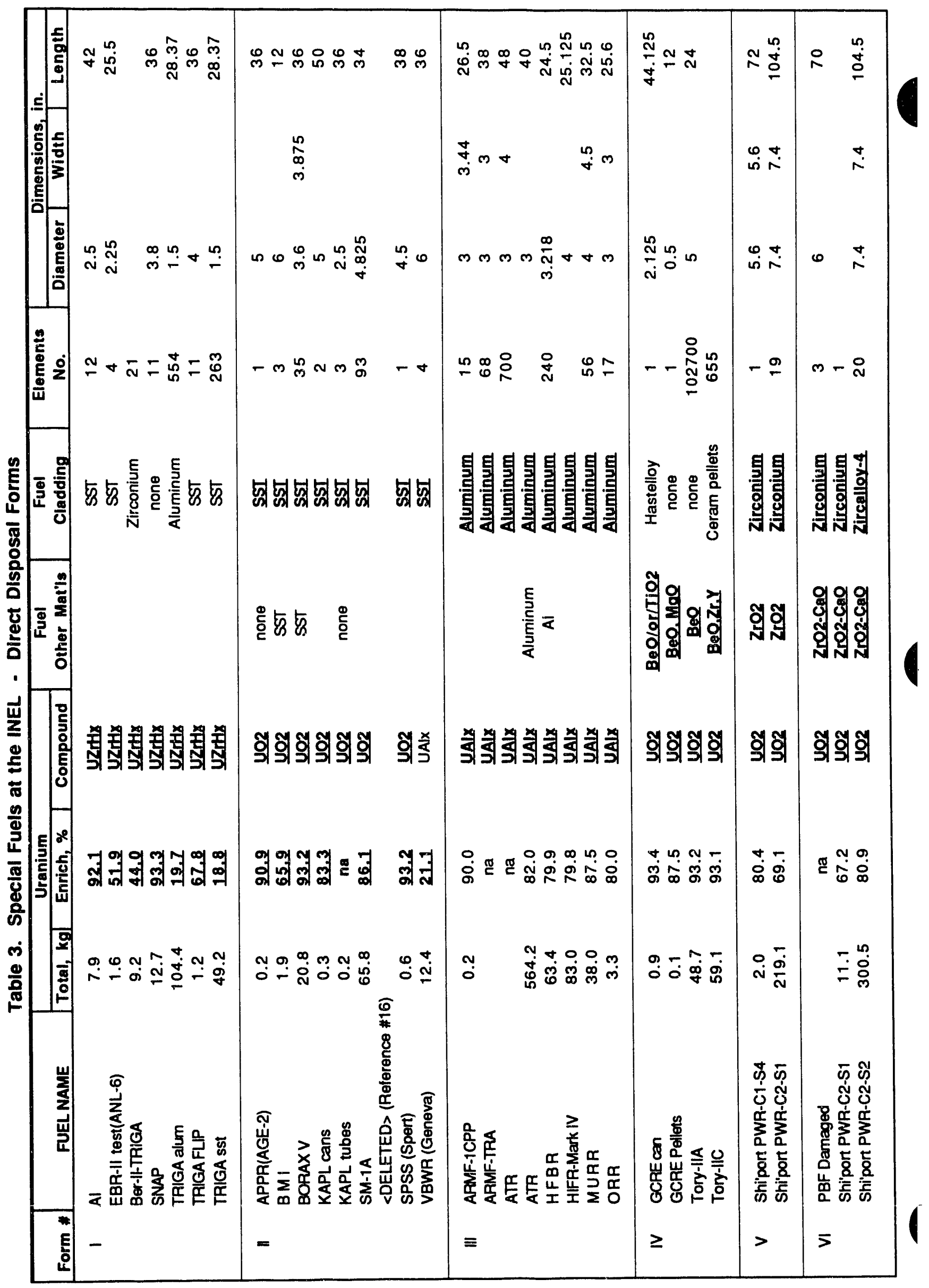




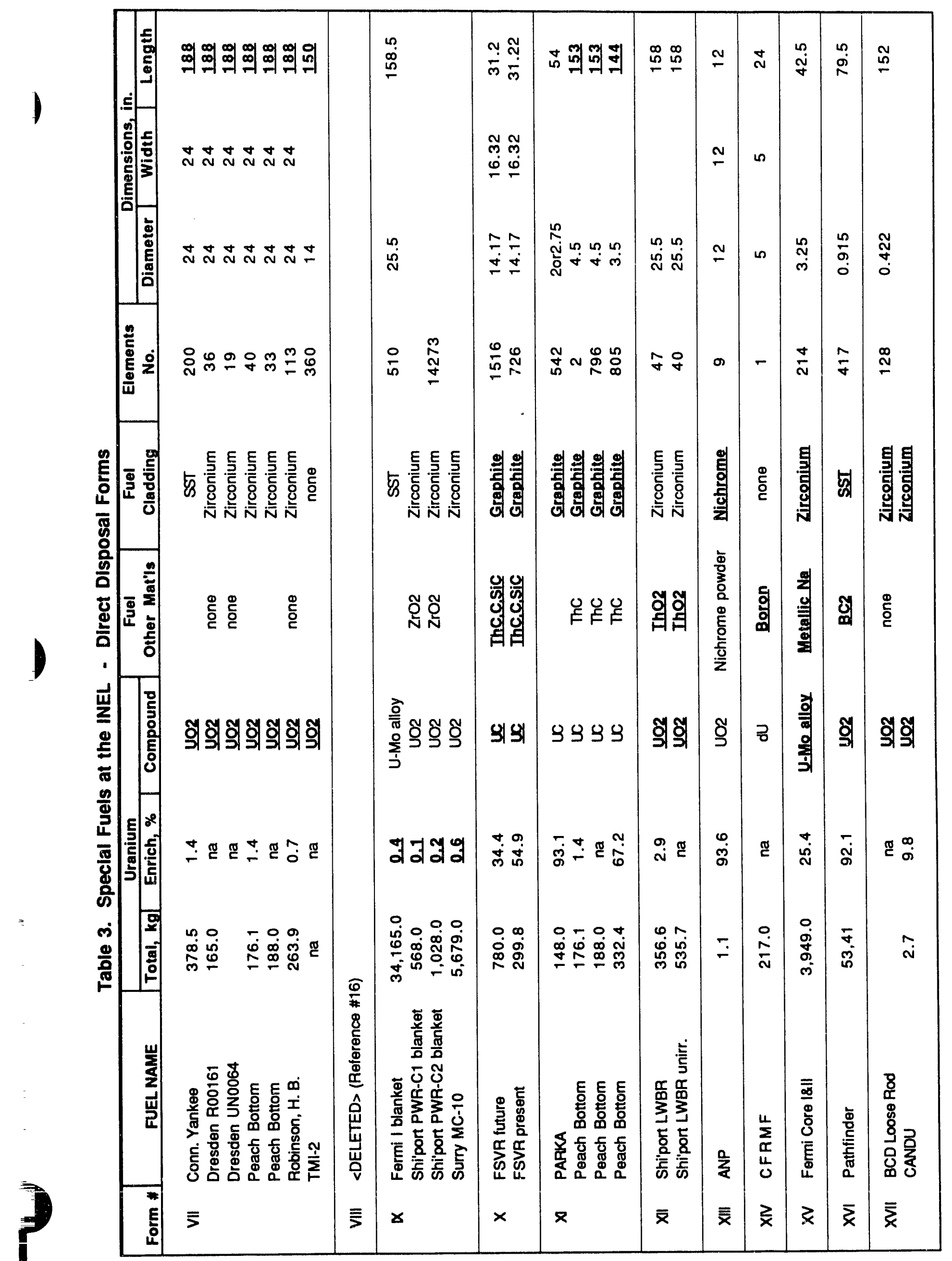




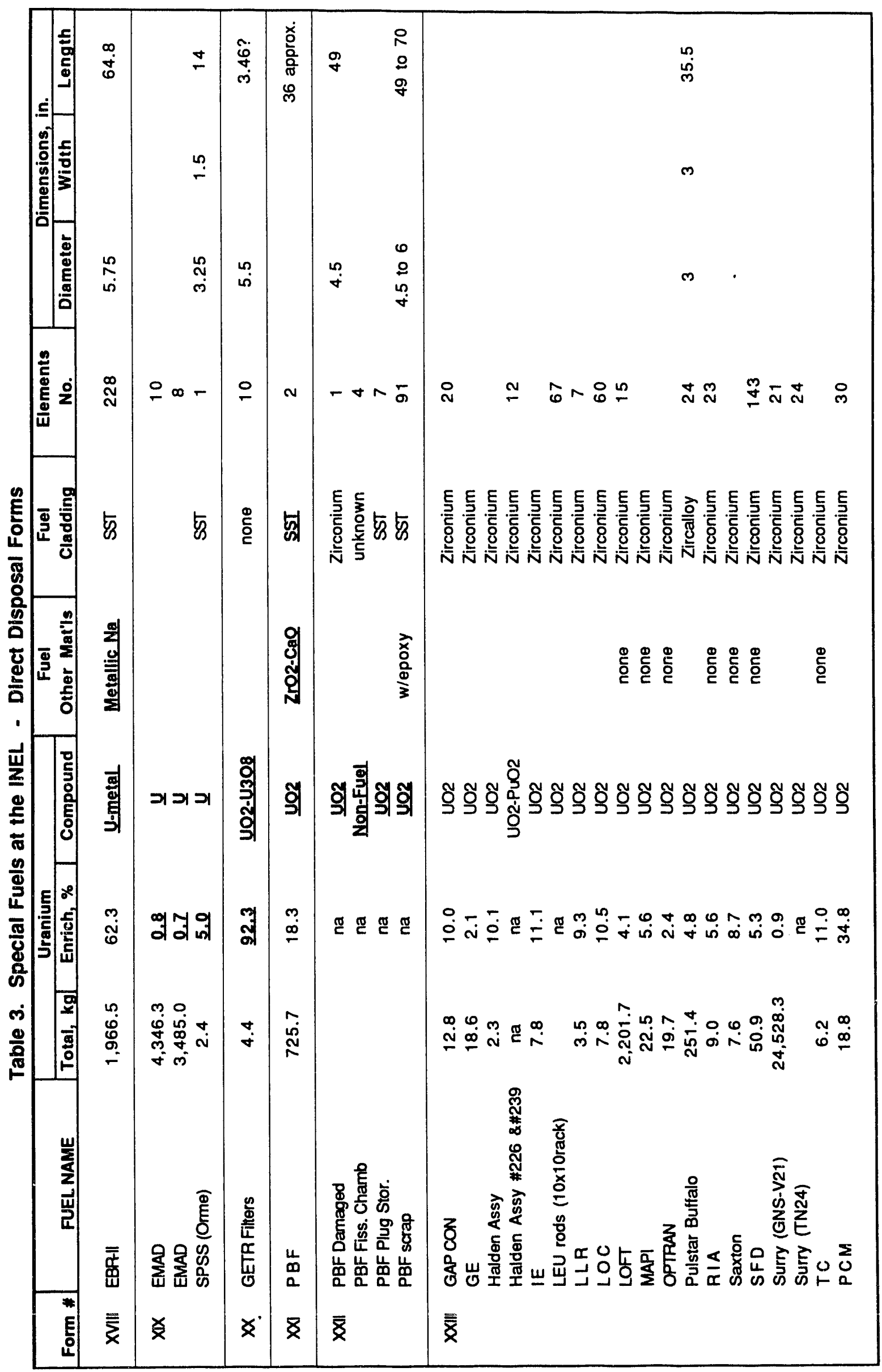


I

)

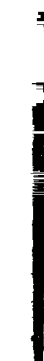

51 


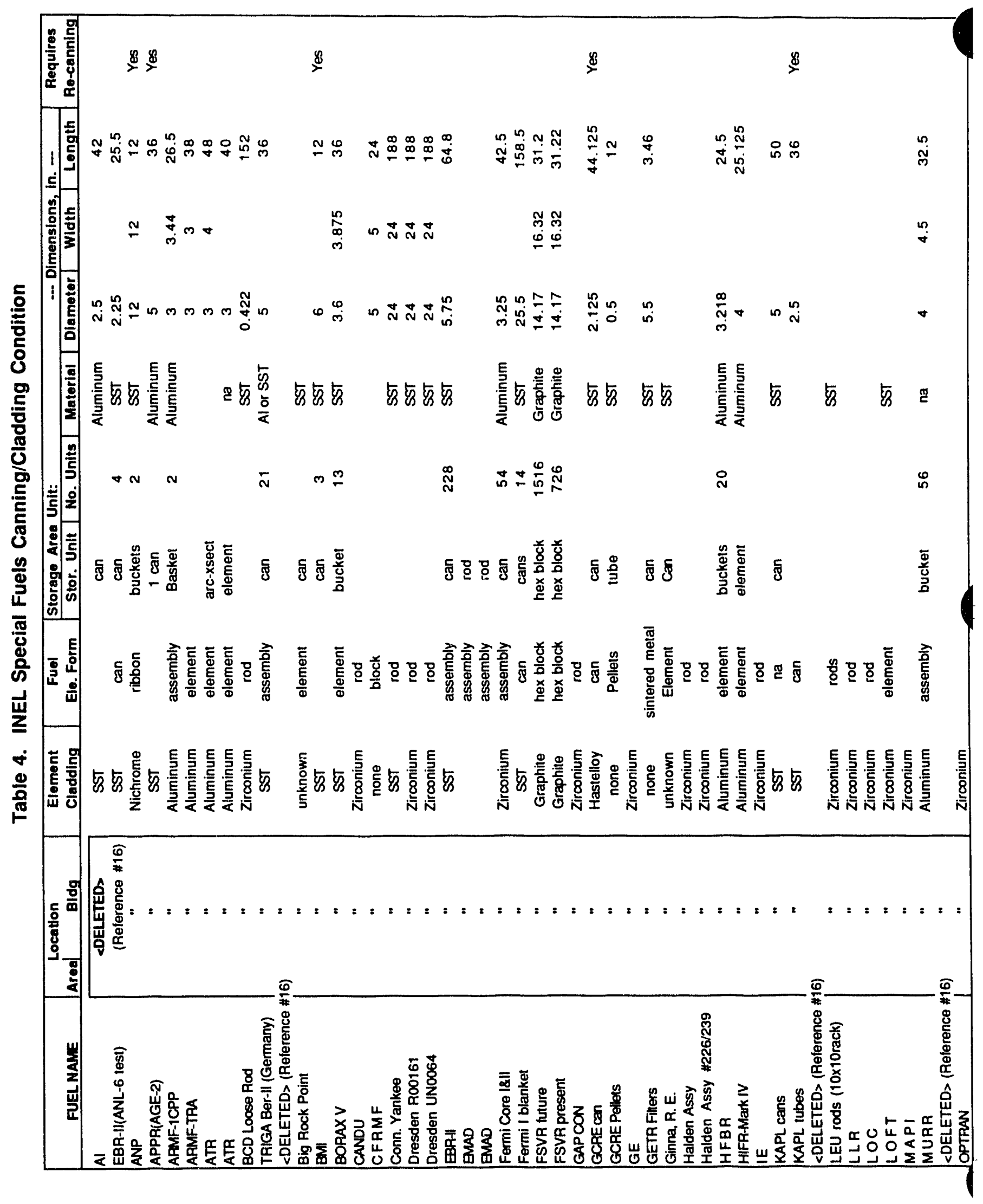




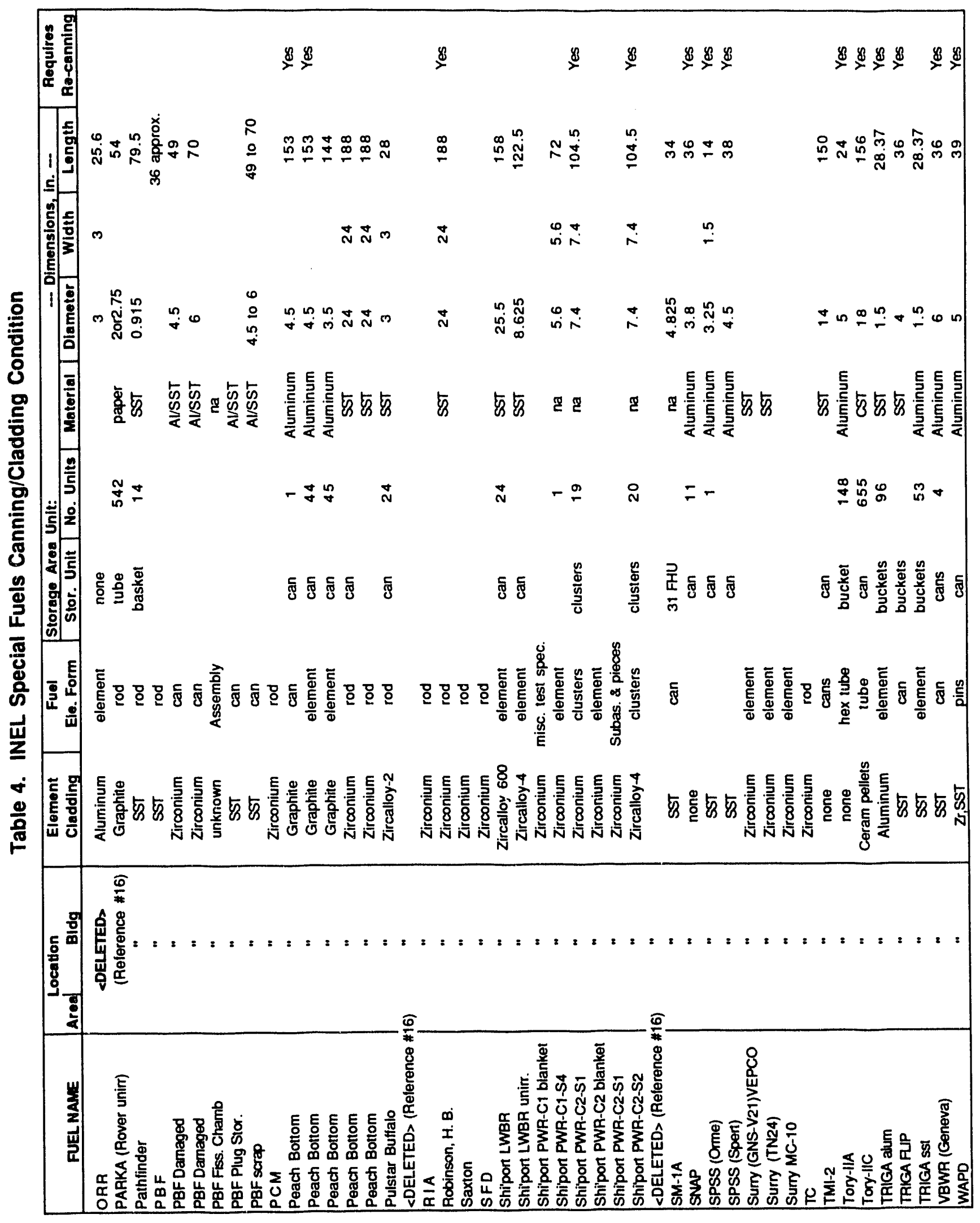




\section{APPENDIX B}

\section{LIST of ACRONYMS}

A-E. . . . . . . A Architectural-Engineering

ALARA ..............as-low-as-reasonably-achievable

DOE. ............... Department of Energy

FAST ............ Fluorinel Dissolution Process and Fuel Storage

FDP.............Fluorinel Dissolution Process

FPR..............Fuel Processing Restoration

HEPA ............ high-efficiency particulate air

HEU. ............... High Enriched Uranium

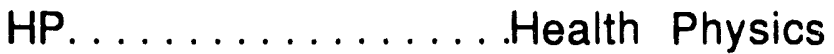

HVAC ............................. ventilation, and air conditioning

ICPP..............ldaho Chemical Processing Plant

INEL .............. Idaho National Engineering Laboratory

NMP ............ Nuclear Materials Production

NWCF ............... Wew Waste Calcining Facility

RCRA ............ Resource Conservation and Recovery Act

ROM ............. rough order-of-magnitude

SFCCF ........... Special Fuels Canning and Characterization Facility

TAN ............ Test Area North

TRA ............. Test Reactor Area

WINCO ........... Westinghouse Idaho Nuclear Co., Inc. 

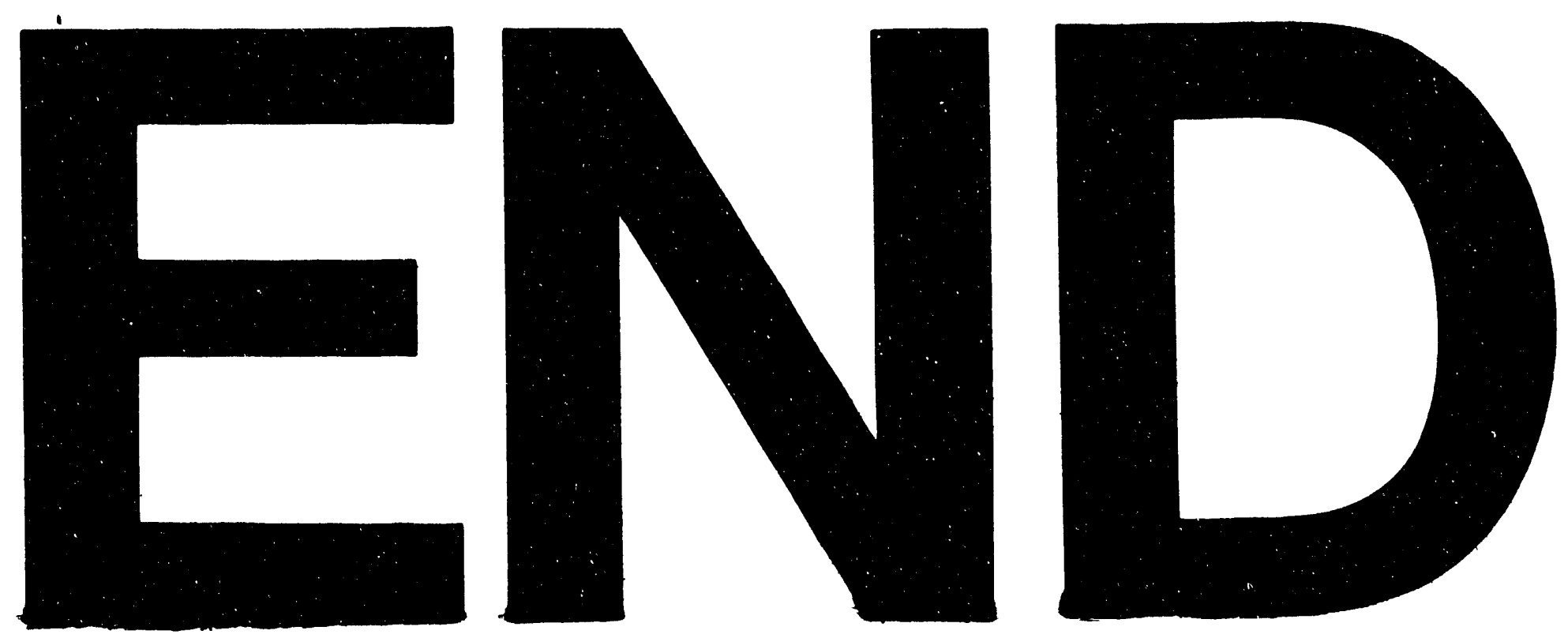

ate
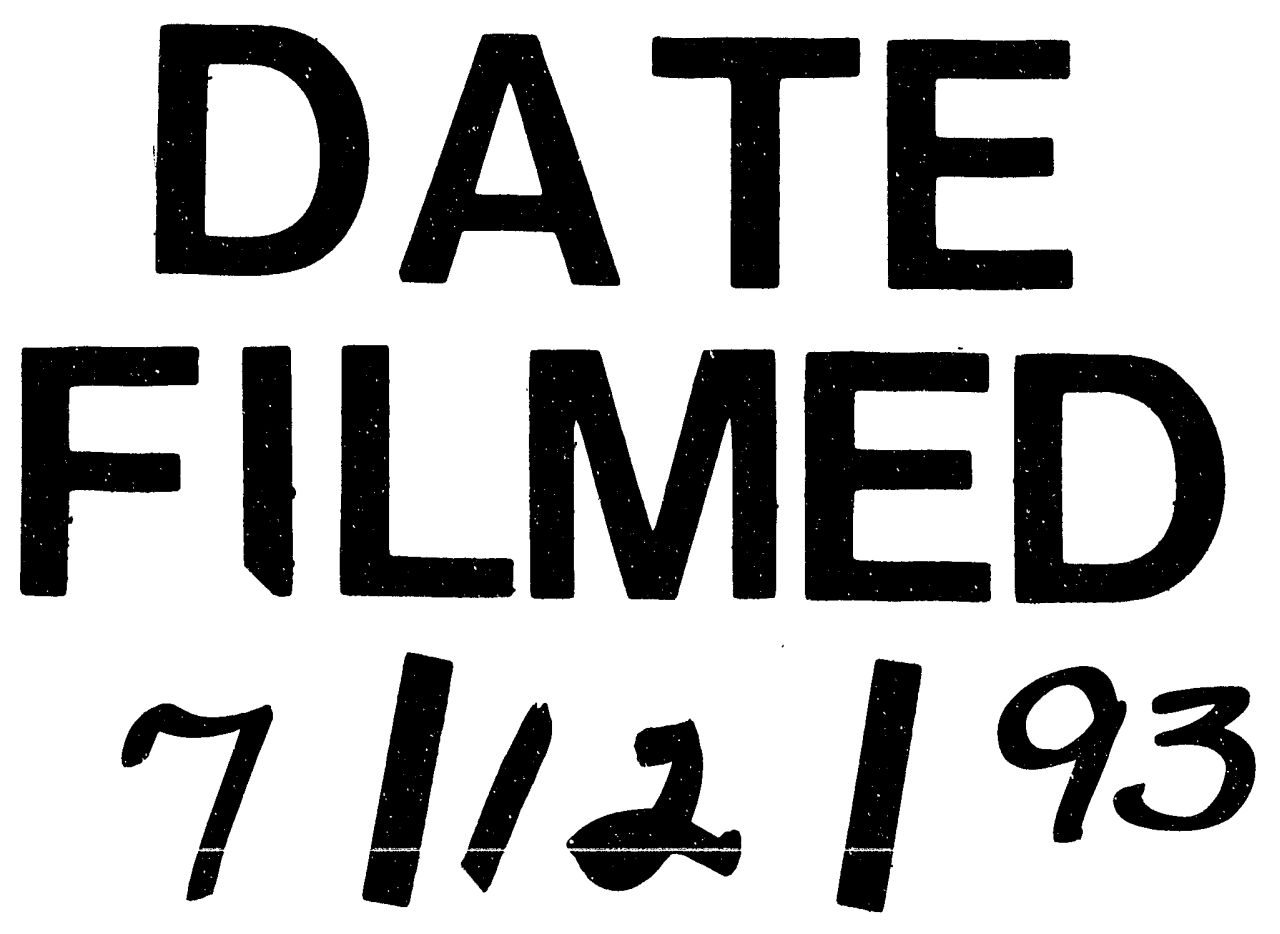

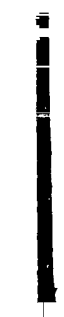


